In Defense of Foxes Guarding Henhouses: The Case for Judicial Acquiescence to IncumbentProtecting Gerrymanders

Author(s): Nathaniel Persily

Reviewed work(s):

Source: Harvard Law Review, Vol. 116, No. 2 (Dec., 2002), pp. 649-683

Published by: The Harvard Law Review Association

Stable URL: http://www.jstor.org/stable/1342612

Accessed: $2 2 \longdiv { / 1 1 / 2 0 1 1 1 2 : 4 1 }$

Your use of the JSTOR archive indicates your acceptance of the Terms \& Conditions of Use, available at http://www.jstor.org/page/info/about/policies/terms.jsp

JSTOR is a not-for-profit service that helps scholars, researchers, and students discover, use, and build upon a wide range of content in a trusted digital archive. We use information technology and tools to increase productivity and facilitate new forms of scholarship. For more information about JSTOR, please contact support@ jstor.org. 


\title{
REPLY
}

\section{IN DEFENSE OF FOXES GUARDING HENHOUSES: THE CASE FOR JUDICIAL ACQUIESCENCE TO INCUMBENT- PROTECTING GERRYMANDERS}

\author{
Nathaniel Persily*
}

\section{INTRODUCTION}

In the wake of the closest presidential election in history, and in an age of unprecedented partisan parity in the U.S. House of Representatives, U.S. Senate, and state governments, few would fault the American political system for its lack of competition. And at a time when judges have become embroiled in politics to an unprecedented degree, even to the point of deciding a presidential election and drawing districts for dozens of legislatures, few would urge courts to reread the Constitution so as to enlarge judges' role to that of trustbusters of perceived political cartels. And when the most prominent "independent" officials overseeing American politics in the last few years have been Kenneth Starr, Katherine Harris, the Florida Supreme Court, and the U.S. Supreme Court, few retain their faith in the notion of nonpartisan supervision of elections.

Samuel Issacharoff is one of the few. His thoughtful and provocative article ${ }^{1}$ urges courts to read the Constitution to enforce a prophylactic rule that would have the effect of declaring all current districting schemes unconstitutional because they were drawn by self-interested decisionmakers. Two distinct benefits would flow from this jurisprudential move, according to Issacharoff. First, nonpartisan redistricting would lead to increased intradistrict electoral competition, which in turn would lead to greater responsiveness and accountability in government. Second, by adopting a prophylactic rule that deems all purposeful redistricting suspect, the Court would put an end to the ra-

* Assistant Professor, University of Pennsylvania Law School. Richard Pildes, Heather Gerken, Elizabeth Garrett, Pamela Karlan, Bruce Cain, John Hart Ely, Richard Hasen, Phil Weiser, Michael Dorf, Seth Kreimer, Kristin Madison, Cathy Struve, Polk Wagner, and Kermit Roosevelt provided helpful comments on earlier drafts. I am also grateful for comments received at faculty workshops at Rutgers-Camden, University of Miami, and University of Pennsylvania Law Schools. Lauren Goldbeck, Christopher Seaman, and Amanda Segal provided excellent research assistance and help producing the tables and graphs. Thank you also to Sam Issacharoff for graciously agreeing to this exchange and to the excellent Harvard Law Review editors who shepherded it to completion.

$\rightarrow$ Samuel Issacharoff, Gerrymandering and Political Cartels, I I6 HARV. L. REV. 593 (2002). 
cialization of political redistricting fights resulting from partisan actors' seeking judicial redress through the limited tools of the uncertain Shaw doctrine ${ }^{2}$ and the Voting Rights Act. ${ }^{3}$

I disagree fundamentally, but I hope respectfully, with almost every aspect of Issacharoff's argument. First, I disagree with his definition and his assessment of the problem he wishes to solve. By focusing on incumbent reelection rates and margins of victory, Issacharoff ignores evidence both of intense competition for control of legislatures and of remarkable levels of legislative turnover. Second, to the extent incumbents have unfair and growing advantages over challengers, redistricting is not to blame. We know this because statewide elections unaffected by redistricting, such as elections for governor and U.S. Senate, have shown parallel growth in rates of incumbent reelection. Third, the creation of safe seats, the principal target of Issacharoff's ire, is neither inherently undesirable nor easily avoidable. Although intradistrict partisan competition may suffer from bipartisan gerrymanders, representation may be the beneficiary. There is no a priori reason to prefer a districting system that produces many competitive races over one that produces proportional representation. In fact, given that competitive districts may lead both to greater power for the ideologically centrist, median voter and to almost half of the voters' being unhappy with their representative, there is good reason to consider safe districts preferable from the standpoint of democratic theory. Moreover, states have legitimate interests in sending a congressional delegation to Washington that has the greatest possible seniority and in keeping experienced legislators in state government. Fourth, redistricting by politically insulated commissions, the alternative that Issacharoff would have the courts force upon state governments, is both undesirable in theory and difficult to create in fact. If our experience with independent counsels or with those overseeing the 2000 election debacle did not dispel the myth of nonpartisan oversight of politics, an analysis of current redistricting commissions and the Federal Election Commission should. Indeed, the whole enterprise of expanding or reconceptualizing judicial authority in the political sphere to include a role as trustbuster of political cartels is fraught with problems. If anything, recent experience argues in favor of a judicial retreat from the political thicket.

2 See Shaw v. Reno, 509 U.S. 630 (1993) (holding that districts unexplainable on grounds other than race are subject to strict scrutiny under the Equal Protection Clause).

342 U.S.C. \$§ I97 I, I973-I973p (2000). 


\section{GERRYMANDERING, POLITICAL MARKETS, AND THE LAW OF DEMOCRACY}

Through casebooks and dozens of articles, Professor Issacharoff and his frequent coauthors, Pamela Karlan and Richard Pildes, have helped craft the new field of study they have termed "The Law of Democracy." 4 Although the Supreme Court's decision in Bush v. Gore ${ }^{5}$ may have brought the field into the spotlight, the issues of voting rights, redistricting, campaign finance, political parties, and regulation of the ballot had been the source of considerable, even if disconnected, study for some time. Now a clearly defined discipline straddling constitutional and statutory law has emerged to sew together these related topics of access to political power and organization of the political process.

Recently, thanks largely to Issacharoff and Pildes's work, ${ }^{6}$ attention in the field has shifted from a discussion of rights of participation and political access to an analysis of the background structures and organization of the electoral system. Most notably, the debate has revolved around the desirability of a jurisprudential shift away from rightsbased analysis toward an emphasis on electoral competition. ${ }^{7}$ In his

4 Samuel issacharoff, Pamela S. Karlan \& Richard H. Pildes, The Law of Democracy: Legal STRUCTURe of the POlitical Process (2d ed. 200I); see also

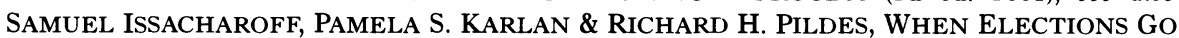
BAD: The LaW of Democracy AND THE PRESidential Election of 2000 (rev. ed. 200I); Daniel hays Lowenstein \& RichaRd L. HASEN, Election LaW: CASES AND MATERIALS (2d ed. 200I); Symposium, Election Law as Its Own Field of Study, 32 LOY. L.A. L. REV. 1095, 1095-272 (1999) (presenting several articles describing the formation of Election Law as an independent discipline).

5 53I U.S. 98 (2000).

$6, \rightarrow$ Samuel Issacharoff \& Richard Pildes, Politics as Markets: Partisan Lockups of the Democratic Process, 5o STAN. L. REV. 643, 645-46 (I998).

7 See, $\epsilon \rightarrow$ Bruce E. Cain, Garrett's Temptation, 85 VA. L. REV. 1589, I603 (19! $\rightarrow$ Elizabeth Garrett, The Law and Economics of "Informed Voter" Ballot Notations, 85 VA. L. REV. 1533 $(\mathrm{I} 9 \mathrm{\rightarrow} \rightarrow$ Richard L. Hasen, The "Political Market" Metaphor and Election Law: A Comment on Issacharoff and Pildes, 50 STAN. L. REV. 719, 724-28 (19! $\rightarrow$ Samuel Issacharoff, Private Parties with Public Purposes: Political Parties, Associational Freedoms, and Partisan Competition, IOI COLUM. L. REV. 274, 276 (200I); Samuel Issacharoff, Oversight of Regulated Political Markets, 24 HARV. J.L. \& PUB. POL'Y 91, 98-I00 (20 $\rightarrow$ Pamela S. Karlan, Politics by Other Means, 85 VA. L. REV. I697, I698-99 (19 $\rightarrow$ Daryl J. Levinson, Market Failures and Failures of Markets, 85 VA. L. REV. I 745 (1999); Daniel H. Lowenstein, The Supreme Court Has No Theory of Politics - And Be Thankful for Small Favors, in THE U.S. SUPREME COURT AND THE ElECTORAL PROCESS 245, 258-63 (David K. Ryden ed., 2000); Nathaniel Persily, Candidates v. Parties: The Constitutional Constraints on Primary Ballot Access Laws, 89 GEO. L.J. 2 I8I, 2 I89-9 I $(20 \rightarrow$ Nathaniel Persily \& Bruce E. Cain, The Legal Status of Political Parties: A Reassessment of Competing Paradigms, I0o COLUM. L. REV. 775, 788-9I (2000); Nathaniel Persily, Toward a Functional Defense of Political Party Autonomy, 76 N.Y.U. L. REV. 750, 794-805 (200I) [hereinafter Persily, Functional Defen $\rightarrow$ Richard H. Pildes, The Theory of Political Competition, 85 VA. L. REv. 1605, I6I I (1999); Richard H. Pildes, Two Conceptions of Rights in Cases Involving Political "Rights", 34 HOUS. L. REV. 323, 325 (1997). 
contribution here, Issacharoff provides the most concrete application of the political markets paradigm ${ }^{8}$ to date, arguing that competitiveness concerns warrant judicial invalidation of all purposeful redistricting. He should be applauded for sticking his neck out so far, if for no other reason than that he forces us to analyze both the underlying purposes of districted elections and the data on competition throughout the American electoral system.

Although I find so much of the competition argument problematic, this admirable strategy of finding a way out of the Shaw morass, if successful, might warrant adoption. The incoherence of the Shaw doctrine and its natural consequence, acting alongside the Voting Rights Act, of forcing partisan conflict to be expressed as racial conflict led to racially charged litigation that forced courts to wallow in the political thicket for the past ten years. If a prophylactic rule could curtail judicial involvement in redistricting, that single benefit might outweigh the costs. I have my doubts as to whether Issacharoff's proposal would achieve that goal and whether the current round of redistricting litigation will be similar to the last. 9 Nevertheless, I would celebrate this proposal, despite its drawbacks, if it could reverse the trend Issacharoff and I find troubling.

Most would criticize Issacharoff's argument, as well as the political markets approach more generally, on the grounds that it is completely disconnected from the text of the Constitution. I would join in that chorus, but this response seeks to argue against Issacharoff on his own terms. Moreover, reading the Constitution to require nonpartisan redistricting may not require as radical a departure from current constitutional interpretation as one might suspect. If the Court chose to combine its analysis in the Shaw line of cases with its analysis in the patronage cases, ${ }^{10}$ then it would achieve a constitutional rule of deci-

8 See generally Persily \& Cain, supra note 7, at 788-9I (discussing the markets paradigm of judicial regulation of politics).

9 Although the Shaw cause of action proved to be a thorn in the side of several state legislatures and the Supreme Court throughout the I99os, there is good reason to believe the 2000 round will be different. Despite Shaw's incoherence, courts in the 2000 round have appeared to muddle through with strange success in the early litigation. Despite many attempts to knock down redistricting plans on Shaw grounds, not a single Shaw claim is currently on its way to the Supreme Court. I am indebted to discussions with Richard Pildes for this point. For a summary of redistricting litigation following the 2000 census, see Redistricting Cases: The 200os, at http://www.senate.leg.state.mn.us/departments/scr/redist/redsum2000/redsum2000.htm (last visited Nov. 6, 2002).

10 See, e.g., O'Hare Truck Serv., Inc. v. City of Northlake, 5 I 8 U.S. 7 I 2, 726 (I996) (extending protection against partisan retaliation to independent contractors); Branti v. Finkel, 445 U.S. 507 , 520 (1980) (upholding injunction preventing newly elected Democrat public defender from discharging Republican assistants); Elrod v. Burns, 427 U.S. 347,369 (I976) (striking down dismissals from government employment based on partisan affiliation). 
sion preventing partisanship from being the predominant factor in the creation of a district. ${ }^{11}$

Of course, the Supreme Court's decisions in Gaffney v. Cummings ${ }^{12}$ and the most recent Shaw case, Easley v. Cromartie, ${ }^{13}$ make adoption of this theory unlikely. Gaffney, which preceded most of the patronage cases, specifically upheld the creation of safe seats based on a theory of partisan fairness. ${ }^{14}$ And Easley, as Issacharoff notes, established redistricting based on incumbent protection or rank partisanship as a safe harbor from a Shaw claim. In other words, when confronted with the charge that race motivated the creation of a district, a jurisdiction can defend itself by saying that zealous attention to partisanship and incumbent protection, rather than race, was the real cause of the district's shape. This is the problem that Issacharoff takes as his point of departure, initiating a quest toward the destination of taking politics out of the redistricting process.

\section{Defining The PROBlem AND Determining ITS EXISTENCE}

Incumbent control of the redistricting process is cause for concern, argues Issacharoff, because such control allows insiders to become entrenched by immunizing themselves from competition. This entrenchment or immunity from the competitive pressures of a healthy democracy is revealed in the high rates of incumbent reelection and large margins of victory in races for state legislature and the U.S. House of Representatives. Concentrating on district-level competition, however, distracts attention from abundant evidence of competition in the political system as a whole. More importantly, to the degree that a fear of incumbent entrenchment drives this approach, high rates of legislative turnover show that fear to be unfounded.

11 Shaw and its progeny laid down the rule that the Equal Protection Clause prohibits states from using race (a suspect classification) as the predominant factor in the drawing of a district. See Miller v. Johnson, 515 U.S. 900, 916 (1995). The patronage cases stand for the proposition that partisanship is quite like a suspect classification read into the First Amendment. Except at the highest policymaking levels, the state cannot hire, fire, or contract with individuals because of their partisan affiliation. Now, if discrimination based on partisanship is almost always unconstitutional, how can the state justify creating districts drawn predominantly along lines of partisanship, as bipartisan gerrymanders often are? If the use of suspect classifications as the "dominant and controlling rationale" of a districting plan triggers strict scrutiny, id. at 913, it is difficult to envision a partisan or bipartisan gerrymander narrowly tailored toward the achievement of a compelling state interest.

124 I 2 U.S. 735 (1973).

13532 U.S. 234 (200I).

14 Gaffney, 4 I 2 U.S. at $75^{2-53}$. 


\section{A. In Search of Entrenchment}

As a threshold empirical matter, whatever the problems from noncompetitive districts, incumbent entrenchment is not one of them. From Issacharoff's account, one might think that, once elected, incumbents become planted in office for perpetuity. In reality, there has been steady and significant turnover both in Congress and in state legislatures - a quite healthy level of "ritual cleansing"15 despite bipartisan gerrymanders. As Figure I demonstrates, about 10\% to $20 \%$ of the membership of the U.S. House of Representatives has changed in each election over the past thirty years. In fact, it was in the 1992 election - just after the last spate of incumbent-protecting gerrymanders - that the House experienced its largest turnover in recent memory, as more than one quarter of the House membership (I Io representatives) was elected for the first time. As Figures $2 a$ and $2 b$ depict, only about one third of the current House membership was in office a decade ago. Turnover is even greater at the state legislative level. Term limits in seventeen states have ensured that the entire legislative membership will be replaced over the course of a decade, ${ }^{16}$ and even in some states without term limits, turnover has exceeded $30 \% .{ }^{17}$

FIGURE I. TURNOVER IN MEMBERSHIP, U.S. HOUSE OF REPRESENTATIVES, I970-200018

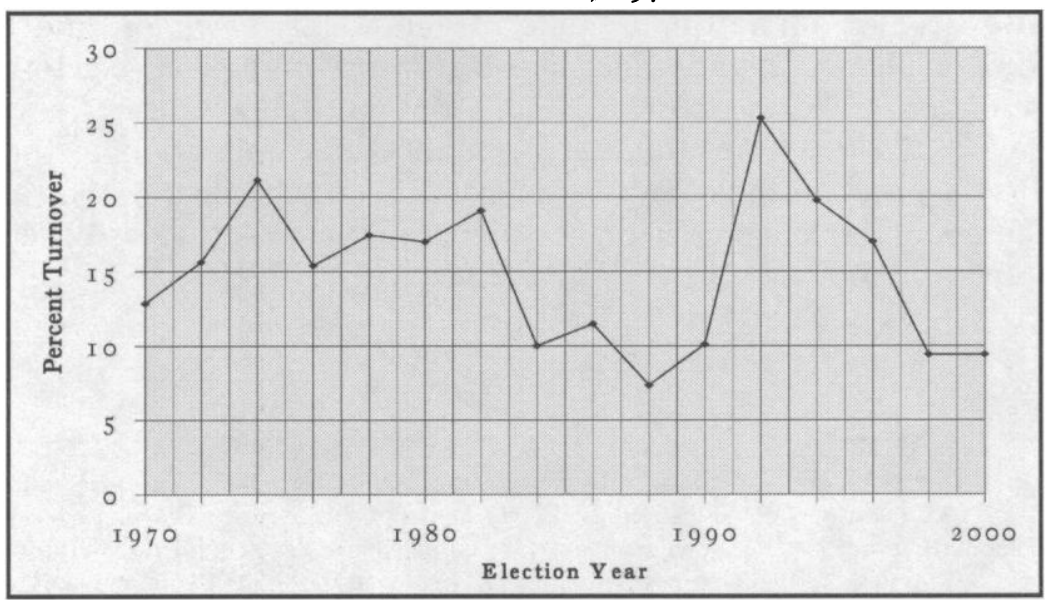

$\rightarrow$ Issacharoff, supra note I, at 6 I 5 (quol $\rightarrow$ Issacharoff \& Pildes, supra note 6 , at 646 ).

16 See National Conference of State Legislatures, Term Limited States by Year Enacted and Year of Impact, at http://www.ncsl.org/programs/legman/about/states.htm (last visited Nov. 6, 2002).

17 See National Conference of State Legislatures, Total Legislative Turnover 1994-06, at http://www.ncsl.org/programs/legman/elect/tottrn.htm (last visited Nov. 6, 2002).

18 See Harold W. Stanley \& Richard G. NiEmi, Vital Statistics on american POLITICS 46 tbl.I-I3, 5I tbl.I-I6 (200I). 
FIGURE 2A. YEAR OF FIRST ELECTION FOR CURRENT MEMBERS OF THE U.S. HOUSE OF REPRESENTATIVES ${ }^{19}$

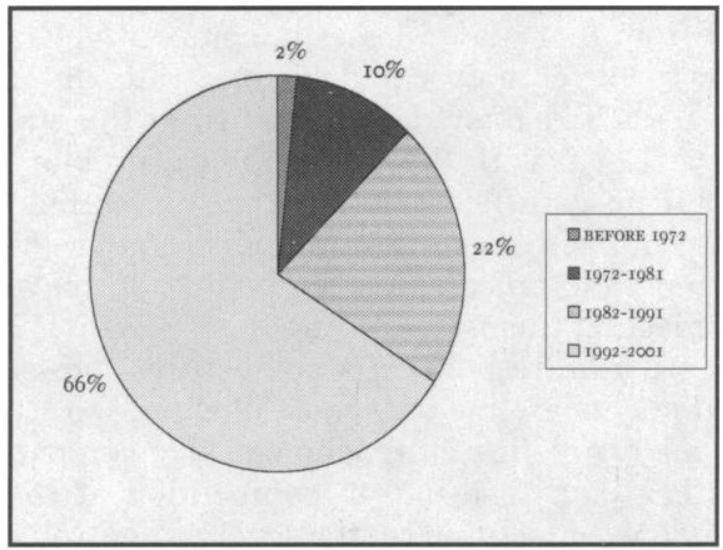

FIGURE 2B. YEAR OF FIRST ELECTION FOR CURRENT MEMBERS OF THE U.S. HOUSE OF REPRESENTATIVES ${ }^{20}$

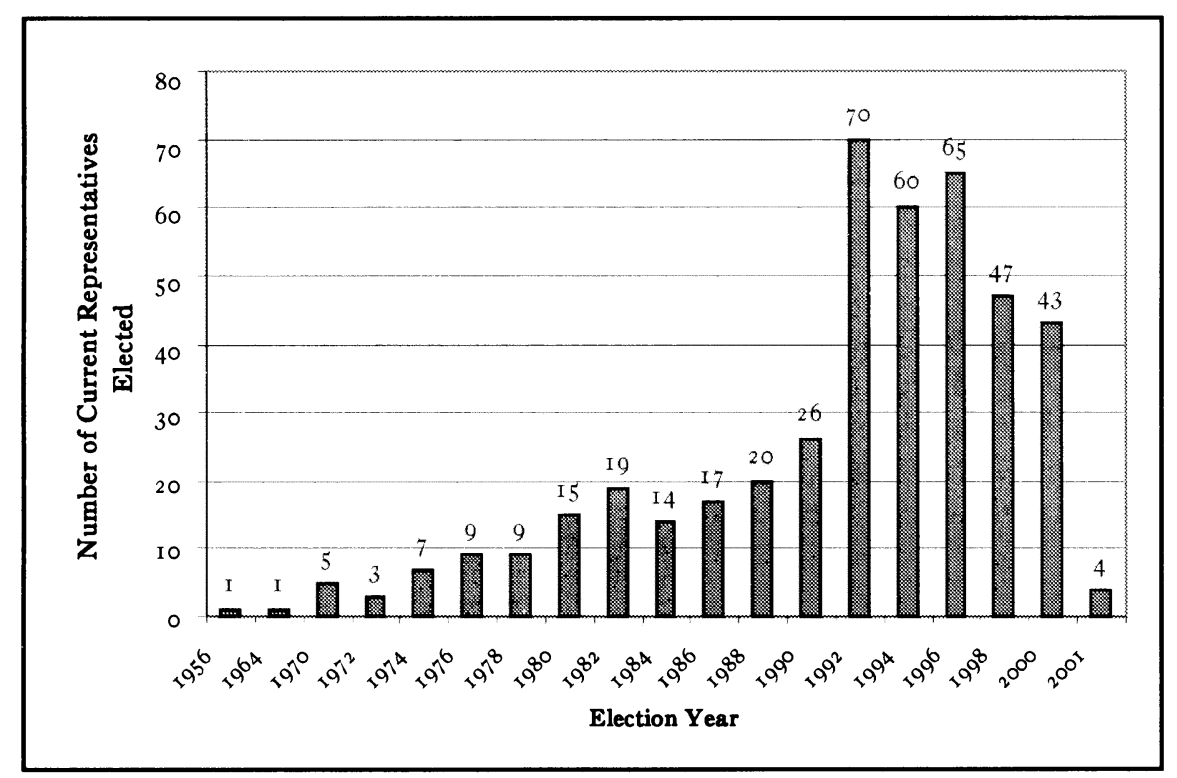

19 See id. at 2 I 4 tbl.5-9.

20 See $i d$. With the exception of $200 \mathrm{I}$, the election years refer to the first regularly scheduled election won by the current members of the House of Representatives. 
Are these rates of turnover so low that they demand judicial intervention for further "ritual cleansing" 21 - or, one might say, ritual sacrifice? Is there really a problem when one third of the House of Representatives has experience and an institutional memory that lasts a decade? Of course, Issacharoff, like most observers, would probably consider turnover due to voluntary retirement and death as qualitatively different from that due to losses in competitive elections: current rates of House turnover may equal historic rates of turnover in the Politburo, but both had their deficiencies from the standpoint of democratic theory. I deal with this philosophical problem in greater detail below. ${ }^{22}$ For now, suffice it to say that representatives in American democracy, unlike in authoritarian regimes, are replaced through a competitive democratic process at some point, and they retain their legitimacy by subjecting themselves to frequent elections. Moreover, retirements are often a response to competitive pressures: weak or threatened incumbents are the ones most likely not to seek reelection. ${ }^{23}$

Of course, one can define entrenchment, like competition, in different ways. Rather than focusing on competition at the district level, one could focus on competition at the level of control of state legislatures. One may have thought that bipartisan gerrymanders have produced a certain partisan stasis in government: that homogeneous districts may turn over, but that the constricting, anticompetitive influences of bipartisan gerrymanders have frozen partisan control and composition of the legislature. Indeed, I would argue that this measure - the frequency of changes in control of the legislature rather than intradistrict competitiveness - is actually a more relevant measure of competitiveness and entrenchment. After all, if the object of this inquiry is to arrive at a set of rules that produces "accountability to shifting voter preferences" 24 and an accurate translation of majority will, then the real question is whether control of the legislature changes in response to changes in the electorate. As it turns out, despite the widespread use of incumbent-protecting gerrymanders, about $13 \%$ of the houses in state legislatures change hands with each election. ${ }^{25}$ True, there are some legislatures that never change hands, principally in those states where the partisan balance in the electorate dramatically

21 See Gary C. Jacobson, Reversal of Fortune: The Transformation of U.S. House Elections in the rggos, in CONTINUITY AND CHANGE IN HOUSE Elections Io, 29 (David W. Brady, John F. Cogan \& Morris P. Fiorina eds., 2000) ("So much for the notion of an ossified Congress desperately in need of term limits for an infusion of new blood.").

22 See infra pp. 66r 165 .

23 See Gary W. CoX \& Jonathan N. Katz, Elbridge Gerry's Salamander: The ELECTORAL CONSEQUENCES OF THE REAPPORTIONMENT REVOLUTION I55 (2002).

$\rightarrow$ Issacharoff, supra note I, at 600 .

25 See Figure 3, infra p. 657. 
favors one party. Yet the I990s was a decade of remarkable competition for control of state legislatures.

Figure 3 displays the rate of turnover of state legislative houses over the last sixty years. In the I990s, on average, eight state senates and six state houses changed hands in each election. Indeed, even in the first election after the 1990 redistricting, eight state houses and twelve state senates changed hands. And in the election following that one, twelve state houses and nine state senates changed hands. By the end of the decade, twenty-nine states had experienced a switch in control of one or the other of their state legislative houses. ${ }^{26}$

\section{Figure 3. Changes in Party Control of State LEGISLATURES, I $940-2000^{27}$}

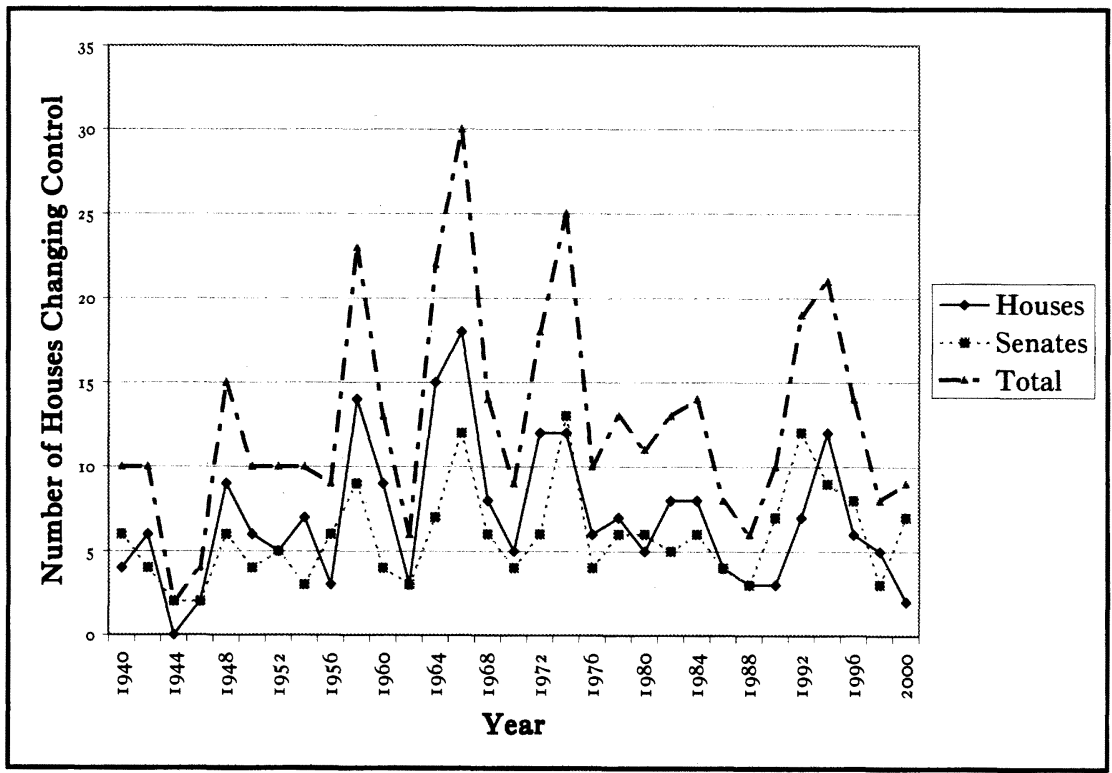

Although the aggregate partisan effects of gerrymanders are not Issacharoff's principal concern, they might be for a judge who takes his advice and assumes the role of political trustbuster. Neither the political markets paradigm nor the proposed prophylactic rule would be confined to incumbent-protecting gerrymanders: duopolistic

26 See National Conference of State Legislatures, Election Data (on file with the Harvard Law School Library).

27 See Nathaniel Persily, Thad Kousser \& Patrick Egan, The Complicated Impact of One Person, One Vote on Political Competition and Representation, 80 N.C. L. REV. I299, I334 fig.2 (2002). 
division of district-level election markets is not inherently different from monopolistic control of a legislature. If one party systematically thwarts majority will through crafty linedrawing that eliminates the prospect of competition for control of the legislature, a judge following the antitrust model would still intervene to eliminate barriers to fair competition. A dominant political party that uses its linedrawing power to eliminate representation of its competitor is not wholly unlike an operating system developer that uses its market position to eliminate competitors in the Internet browser market, for example. Or perhaps more to the point, the economic markets analogy fits as well or as poorly to partisan monopolistic behavior as it does to bipartisan duopolistic behavior. Although bipartisan, rather than partisan, gerrymanders provide the impetus for Issacharoff's proposal, his prophylactic rule would prevent both. ${ }^{28}$

\section{B. The Vanishing Marginals and Incumbent Safety}

Although conceived as an argument against entrenchment and in favor of responsiveness and accountability, the markets position as applied to gerrymandering is really about incumbent safety. Issacharoff is chiefly concerned with creating conditions under which incumbents are more likely to lose or, at least, less likely to win by large margins. ${ }^{29}$ Incumbents are "entrenched," under this view, because when they decide to run, they almost never lose. His argument builds on the evidence marshaled by a group of scholars over the past thirty years who have observed that the number of marginal districts (that is, districts where a candidate wins the general election by less than ten percent or twenty percent) has steadily declined and the rates of incumbent reelection have increased. ${ }^{30}$ Although the data are incontrovertible, the

28 Issacharoff echoes Justice O'Connor and Bruce Cain's argument that partisan gerrymanders are self-regulating. I am not aware of any detailed empirical analysis of this phenomenon. The most that I think can be said is that some, but not all, partisan gerrymanders are selfregulating. Self-regulation depends on certain preconditions as to the geographic dispersion of party adherents within the relevant jurisdiction, and how greedy the dominant party is trying to be. I should also note that it is often difficult to distinguish between a partisan and a bipartisan gerrymander. For the party in control of the redistricting process, incumbent protection is sometimes the best strategy to maintain a majority in the legislature. See Davis v. Bandemer, 478 U.S. IO9, I52 (I986) (O'Connor, J., concurring in the judgment) (citing BRUCE CAIN, THE REAPPORTIONMENT PUZZLE I54-55 (I984)).

$29 \rightarrow$ Issacharoff, supra note $\mathrm{I}$, at 600 .

30 GaRy C. Jacobson, THE POlitics of CONGRessional EleCtions 2 I-30 (200I); THOMAS E. MANN, UNSAFE AT ANY MARGIN: INTERPRETING CONGRESSIONAL EleCtions 15-18 (1978); John A. Ferejohn, On the Decline of Competition in Congressional Elections, 7I AM. POL. SCI. REv. I66, I74 (I977); David R. Mayhew, Congressional Elections: The Case of the Vanishing Marginals, 6 POLITY 295, 304 (1974); Edward R. Tufte, The Relationship Between Seats and Votes in Two-Party Systems, 67 AM. POL. SCI. REV. 540, 550-53 (I973); see also Persily, Kousser \& Egan, supra note 27, at $\mathrm{I}_{32} \mathrm{I}-27$ (summarizing the literature on incumbency advantage and vanishing marginals). 
story that underlies them is much more complicated than first appearances might suggest.

First, high rates of incumbent reelection present a biased description of incumbent invincibility based on the incumbents who seek reelection. This approach ignores the fact that vulnerable incumbents often resign when they face tough challenges. One of the reasons incumbents "win big" is that popular incumbents are the ones who seek reelection and deter potentially strong challengers from running. ${ }^{31}$ What appears at first glance to be incumbent entrenchment is partly explained as self-selection by risk-averse candidates. ${ }^{32}$ Conversely, high-quality challengers often bide their time until a seat becomes open or an incumbent becomes vulnerable. ${ }^{33}$ Thus, popular incumbents rarely square off against the types of candidates who might pose a credible threat and gain close to half the vote.

Second, a district's "marginality" does not necessarily indicate its competitiveness: the safety of a seat in one year may not be determined by the electoral margin in previous years. In other words, an incumbent who wins by twenty percent in one election is truly "safe" only if she can expect to win by such a margin in the next election. Political scientist Gary Jacobson, in The Marginals Never Vanished, argued that interelection vote swings had gotten larger in the I970s and thus, incumbents who won by large margins in one election were not necessar-

31 See Cox \& KATZ, supra note 23, at $140-6 \mathrm{I}$; Gary W. Cox \& Jonathan N. Katz, Why Did the Incumbency Advantage in U.S. House Elections Grow?, 40 AM. J. POL. SCI. 478, 482-83 (1996); Jacobson, supra note 21 , at $\rightarrow$ Thomas A. Kazee, The Deterrent Effect of Incumbency on Recruiting Challengers in U.S. House Elections, 8 LEGIS. STUD. Q. 469, 469 (I9 $\rightarrow$ Jonathan S. Krasno \& Donald Philip Green, Preempting Quality Challengers in House Elections, $50 \mathrm{~J}$. POL. 920, 932-33 (1988).

32 Recent experience with New York's Nineteenth and Twenty-Eighth congressional districts illustrates this point. The bizarrely shaped, heavily Democratic Twenty-Eighth District stretches from Rochester to Buffalo and originally paired powerful Democratic incumbents John LaFalce and Louise Slaughter. The Republican Nineteenth District straddles the Hudson Valley just above Westchester, originally pairing Republican Representatives Benjamin Gilman and Sue Kelly. Both districts were the product of a bipartisan gerrymander. See The New York State Legislative Task Force on Demographic Research and Reapportionment, View District Maps, at http://latfor.state.ny.us/maps (maps of the districts). However, both districts had the potential to produce very competitive primary races between the sitting incumbents. Those competitive races never materialized because LaFalce and Gilman chose not to run for election once the map was drawn. See Adam Clymer, Congressman LaFalce To Retire, N.Y. TIMES, June 27, 2002, at B4; Editorial, Ben Gilman Steps Down, N.Y. POST, July 10, 2002, 2002 WL 2235457 I. Districts that looked very competitive under one set of conditions became extremely uncompetitive since Representatives Slaughter and Kelly did not face credible primary challenges and did not face serious general election challenges.

33 See Cox \& Katz, supra note 23 , at 478 (suggesting that incumbents' ability to scare off quality challengers accounts for much of the incumbency advantaL $\rightarrow$ Kazee, supra note 3I, at 478 ;

$\rightarrow$ Krasno \& Green, supra note 31, at 933 . 
ily safe for the next election. ${ }^{34}$ Although the argument may be less accurate for later decades, ${ }^{35}$ the empirical evidence of incumbent behavior continues to suggest, in Tom Mann's words, that incumbents feel "Unsafe at Any Margin." 36 In other words, incumbents behave as if their growing margins of victory do not indicate that their seats are safe. Or to put it differently, there is no evidence for Issacharoff's suggestion that safe districts have produced unresponsive representatives. As Stephen Ansolabehere, David Brady and Morris Fiorina explain:

Whatever the reasons, an incumbent's margin in the previous election is not as good an indicator of prospects in the next election as it once was. Thus, the electoral uncertainty facing incumbents has increased. Consequently, they are going home more frequently, allocating increasing resources to the district, and in myriad ways "working" their constituencies .... There is simply no evidence that larger election margins have made today's incumbents less responsive to their constituencies than were those of yesteryear. ${ }^{37}$

This continuing responsiveness of elected officials provides one of the answers to Issacharoff's hyperbolic comparison of bipartisan gerrymanders to the elimination of elections. ${ }^{38}$ Even admitting, as one must, that redistricting by partisan officials allows them to skew the outcomes of elections, self-interested gerrymanders do not remove elections' "after-the-fact capacity to vote [incumbents] out of office."39 Voters are still capable of casting votes based on the retrospective judgments of incumbent performance, and the threat of a serious challenge or removal remains to keep incumbents honest, so to speak. Indeed, one might ask why incumbents spend so much time raising money for their campaigns if they are in a position truly comparable to representatives installed by an enlightened despot who has properly assessed the preferences of the citizenry.

34 Gary C. Jacobson, The Marginals Never Vanished: Incumbency and Competition in Elections to the U.S. House of Representatives, 1952-82, 3 I AM. J. POL. SCI. I26, I26, I30, I33 (1987); see also Stephen Ansolabehere \& James M. Snyder, Jr., The Incumbency Advantage in U.S. Elections: An Analysis of State and Federal Offices, 1942-200o, I ELECTION L. J. 315, 325 (2002).

$35: \rightarrow$ Stephen Ansolabehere, David Brady \& Morris Fiorina, The Vanishing Marginals and Electoral Responsiveness, 22 BRIT. J. POL. SCI. 2 I, 2 I (I992); Monica Bauer \& John R. Hibbing, Which Incumbents Lose in House Elections: A Response to Jacobson's "The Marginals Never Vanished", 33 AM. J. POL. SCI. 262, 262 (1989).

36 MANN, supra note 30 , at 3 ; $\rightarrow$ Ansolabehere, Brady \& Fiorina, supra note 35 , at 35 .

$\rightarrow$ Ansolabehere, Brady \& Fiorina, supra note 36 , at $27-28$. The authors, like many others, do show a decline in collective responsiveness in the House of Representatives over the past forty years. $\rightarrow i d$. at 29 . However, Issacharoff is concerned with district-level competition and responsiveness, not collective responsiveness at the level of the legislature. A full discussion of institutional responsiveness would require more space than available here. See Persily, Kousser \&

Egan, supra note 27 , at $1319-20$ \& n.57.

$38 \rightarrow$ Issacharoff, supra note $\mathrm{I}$, at $6 \mathrm{I} 3-\mathrm{I} 7$.

$\rightarrow$ Id. at $6 \mathrm{I}_{5}$. 


\section{Gerrymanders, District Composition, and Competition}

To understand additional empirical and theoretical problems in the markets approach to redistricting, it might be useful to step back a moment and identify with greater specificity the types of gerrymanders that Issacharoff finds troubling. Issacharoff views two different, but overlapping, categories of gerrymanders as threats to electoral competition: bipartisan gerrymanders and incumbent-protecting gerrymanders. Bipartisan gerrymanders divide a state into politically more homogenous constituencies with districts that heavily favor either the Democrats or Republicans. Incumbent-protecting gerrymanders, as their name suggests, consist of districts drawn to favor their respective incumbents. Issacharoff puts forth good normative arguments against both types of gerrymanders, ${ }^{40}$ but the differences between them help illustrate some logical and empirical difficulties with his position and proposed remedy.

First, consistent with the antitrust metaphor that drives his argument, Issacharoff urges courts to view with suspicion any division of the political marketplace by the two dominant parties - that is, bipartisan gerrymanders. Because bipartisan gerrymanders create safe seats for one or the other party (irrespective of the particular representative who might benefit), they stifle competition in the general election by calibrating the district's partisan composition so that one party's nominee will be much more likely to win. Of course, this focus on general election competition, like the concern with incumbent reelection rates, ignores competition in primary elections. It is worth noting that thirty-one members of the current Congress received less than $60 \%$ of the vote in their last primary election. ${ }^{41}$ And in the 1992 primaries - the first conducted after the last redistricting - ninety-three districts held primaries where the winner garnered less than $60 \%$ of the vote, and in seventy-eight of those districts, the victor won the primary with $55 \%$ of the vote or less. ${ }^{42}$ Furthermore, some of the most hotly contested races in 2002 occurred in primary elections. ${ }^{43}$ There is no obvious reason why competitive primaries would not produce the

$40 \rightarrow$ id. at 605-II.

41 See Michael Barone \& Richard E. Cohen, The Almanac of American POLITICS 2002 (200I).

42 See Michael Barone \& Grant Ujifusa, The Almanac of american Politics I 994 (I993).

43 See generally Dave Boyer \& Amy Fagan, Leftist Lobbies Suffer a Hit in Michigan Race, WASH. TIMES, Aug. 9, 2002, at $\mathrm{A}_{4}$ (describing the race between Congressman John Dingell and Lynn Rivers); Thomas B. Edsall, Questions Raised About Donors to Georgia Lawmaker's Campaign, WASH. POST, Aug. I3, 2002, at A2 (describing the Georgia House race between Congresswoman Cynthia McKinney and Denise Majette); David Colpo \& Michael Granoff, Letters to the Editor: Hilliard's Own Failure Defeated Him, Not Outsiders, WASH. TIMES, July 5, 2002, at Ar8 (describing the primary election defeat of Congressman Earl Hilliard). 
same advantages of responsiveness, accountability, and "ritual cleansing" that Issacharoff attributes to competitive general elections.

The data on primary elections also highlight a theoretical problem with Issacharoff's argument that might become clear if we ask what appears at first to be a stupid question: why are pure Democratic or Republican districts - the alleged product of cartel-controlled gerrymanders, according to Issacharoff - "noncompetitive"? The obvious answer, as stated above, is that districts so skewed toward advantaging one party give the typical nominee from the out-party almost no chance of winning the general election. But there is nothing inherent in a politically skewed or homogeneous district that makes it noncompetitive. Although Issacharoff's definition of competition is somewhat elusive, it would seem that a competitive district is one with an electorate likely to be closely split between two candidates. That probability is not defined by the partisan composition of the electorate, per se, but by the chance that two candidates of equal appeal and resources will emerge to compete. A bipartisan gerrymander produces seats that are potentially competitive in a primary election, and almost certainly so if an incumbent is not in the race. ${ }^{44}$ Issacharoff provides other objections to bipartisan gerrymanders - that they polarize the two parties and leave the median voter unrepresented - that have nothing to do with competition, per se, and are considered later in this section.

This brings us to the second type of gerrymander that troubles Issacharoff: the incumbent-protecting gerrymander. Some incumbentprotecting gerrymanders are also bipartisan gerrymanders, but they operate under a different principle: namely, to keep the district safe for a particular person. Although such districts are often also drawn to favor the party of the incumbent, in my experience they just as frequently operate under a "least-change" principle. In other words, incumbents try to keep their districts as intact as possible, based on the theory that "if it ain't broke, don't fix it": if the districts have elected them before, they are likely to elect them again. Perhaps the greatest advantages of incumbency are name recognition and a history of constituent work and often favorable news coverage in a given area. Because new voters added to an incumbent's district have had less expo-

44 Even with respect to the general election under bipartisan gerrymandered districts, a "safe" district is noncompetitive because the "typical" candidate from the minority party would be far away from the median voter in the district such that she would have no real chance of victory. But the parties' unwillingness or inability to field a candidate who strays from the party line, not the composition of the district, is then the cause of the lack of competition. 
sure to the incumbent, a campaign would need to spend substantial resources to educate these new voters about the incumbent's record. ${ }^{45}$

So which type of gerrymandering predominates, and what does this say about the inherent competitiveness of congressional districts? Figure 4 breaks down congressional districts according to their levels of competitiveness in the 1992 , I996, and 2000 presidential elections. It demonstrates that a large share, perhaps a majority, of the districts might be considered competitive. Districts labeled competitive are ones in which the presidential candidate won the district by less than I0\% of the vote; in marginal districts the winner won by between 10\% and $20 \%$ of the vote; and in safe districts the winner won by over $20 \%$ of the vote. ${ }^{46}$ The data reveal two interesting and relevant findings. First, congressional districts in the I990s appear much more competitive than an analysis of congressional election returns suggests. If the political parties were colluding to divide up the political market into politically lopsided constituencies, we would not expect to find so many close races based on the presidential vote. Almost half the districts (204) were competitive in the first election after the I990 redistricting, and three-quarters (326) were either competitive or marginal. Even at the end of the redistricting cycle, about $28 \%$ (I 22 ) were competitive and more than half $(256)$ were competitive or marginal. This presents a second notable, even if inexplicable, finding: the number of competitive districts shrank as the effect of redistricting receded into the past. If bipartisan gerrymanders were as dominant as Issacharoff thinks they are, elections closest to the redistricting cycle should be the least competitive, not the most competitive, throughout the decade. As

45 See Stephen Ansolabehere, James M. Snyder, Jr. \& Charles Stewart III, Old Voters, New Voters, and the Personal Vote: Using Redistricting To Measure the Incumbency Advantage, 44 AM. J. POL. SCI. I 7,23 (2000).

46 Political scientists use various measures of marginality and competitiveness. See Persily, Kousser \& Egan, supra note 27 , at 1316 . Figure 4 is organized in such a way that advocates of competing definitions of these concepts can view the data as they see fit. The existence of minor party candidates - Perot in 1992 and 1996 , and Nader and Buchanan in 2000 - does not alter the graph in any significant way. Perot voters, at least in 1992, were perceived as split almost evenly as to who their second choice would be. See R. Michael Alvarez \& Jonathan Nagler, Economics, Issues and the Perot Candidacy: Voter Choice in the 1992 Presidential Election, 39 AM. J. POL. SCI. 714, 737 (" $49.5 \%$ of the Perot voters would have voted for Bush; $50.5 \%$ would have voted for Clinton."). The 2000 election was potentially tricky, given that Nader probably took many more votes from Gore than Buchanan did from Bush. Bearing this consideration in mind, I spliced the data in three different ways to assess competitiveness: (I) percent of the vote received by Bush in the congressional district, (2) (Bush + Buchanan) - (Gore + Nader), and (3) Bush Gore. Although the alternative methods of computation do not change the graph much at all, I chose Option 3, which presents the data in the light most favorable to Issacharoff's argument and maintains consistency across all three elections. Option 2, which is probably the most natural and accurate way to organize the data, produces the following results: 70 safe Republican districts, 67 marginal Republican districts, I3 I competitive districts, 58 marginal Democratic districts, and 106 safe Democratic districts. 
the political composition shifts with the demographic transformation of a district over time, one would expect districts to become less politically homogenous, not more so. The opposite appears to be true.

FigURE 4. COMPETITIVENESS OF CONGRESSIONAL DISTRICTS ACCORDING TO PRESIDENTIAL ELECTION RESULTS, I $992-2000^{47}$

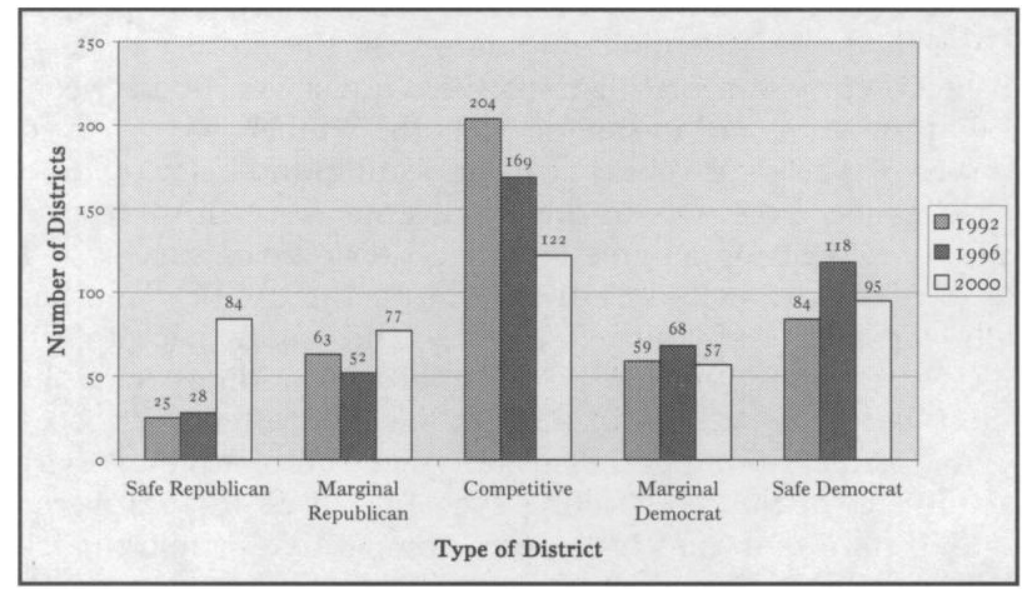

Assuming, for the moment, that redistricting has caused the lack of competition Issacharoff finds troubling, it would appear that incumbent protection, rather than true partisan division of the political marketplace, provides a better explanation for incumbent safety. If most districts were inherently uncompetitive, we would expect to see lopsided results across different types of elections. Furthermore, the data suggest that Issacharoff's concern for the disenfranchised median voter is unfounded. When stripped of the incumbency advantage flowing from the popularity of a particular incumbent, many districts in the I 990 s were, in reality, more evenly balanced between Republicans and Democrats than the congressional election results would indicate. In any case, as the next section explains, the foundational assumption that gerrymandering is responsible for the rising safety of incumbents is problematic.

\section{IS GERRYMANDERING TO BLAME FOR LACK OF COMPETITION AND GROWTH OF INCUMBENT SAFETY?}

After parsing the empirical evidence, we are still left with the indisputable fact that incumbents almost always win big in general elec-

47 See BARONE \& COHEN, supra note 4I; BARONE \& UJIFUSA, supra note 42. 
tions when they choose to run. For the political markets critique of gerrymandering cartels to succeed, however, critics should be able to demonstrate that incumbent-protecting gerrymanders are a significant cause of incumbent safety. The evidence supporting this causal relationship, which seems so patently obvious, is difficult to find. In the most remarkable sentence in his article, Issacharoff suggests that his argument "does not rise or fall" on proving that gerrymandering causes the problems his prophylactic rule seeks to remedy. ${ }^{48}$ That suggestion is as baffling as one made by a doctor who recommends gall bladder surgery to cure a patient's brain tumor. If gerrymandering is not a significant cause of the alleged anticompetitiveness problem, why should we rewrite redistricting law in order to solve it?

The first piece of data that undermines this causal relationship comes from the high reelection rates of incumbents in statewide races, such as those for the U.S. Senate, which are unaffected by redistricting. Although such races tend to be more competitive (that is, margins of victory tend to be lower), in the last decade incumbent U.S. Senators have fared about as well as House members when they have run for reelection. ${ }^{49}$ If bipartisan gerrymanders were to blame for incumbent safety, then we would expect reelection rates in the House to be much higher than in the Senate. As Table I reveals, in the past decade the rates were comparable: on average, about $90 \%$ of Senators and $95 \%$ of House members who sought reelection won. Recent research on elections for governor and other statewide offices similarly unaffected by redistricting, such as Attorney General, has shown incumbency advantages sometimes even exceeding those for House incumbents. ${ }^{50}$

$\rightarrow$ Issacharoff, supra note I, at 626 .

49 See Kenneth Collier \& Michael Munger, A Comparison of Incumbent Security in the House and Senate, 78 PUB. CHOICE I45 (I994); Amihai Glazer \& Bernard Grofman, Two Plus Two Plus Two Equals Six: Tenure in Office of Senators and Representatives, 1953-1983, I2 LEGIS. STUD. Q. 555 (I987).

50 See Ansolabehere \& Snyder, supra note 34 . There is a difference between the incumbency advantage and incumbent safety. The incumbency advantage describes the additional vote percentage that an incumbent can expect merely because she is an incumbent. Nevertheless, the authors' conclusion about the relationship between redistricting and the incumbency advantage undermines Issacharoff's argument. In Ansolabehere and Snyder's words:

Redistricting seems especially unlikely to contribute additionally to the incumbency advantage. The U.S. Senate and U.S. House have comparable incumbency advantages in all but the last decade of our analysis, while only the House has redistricting. Similarly, state executives are never redistricted, and nonetheless have higher incumbency advantages than state legislators.

$I d$. at 326 . In any event, it should be noted that the incumbency advantage in House elections appeared to decline in the I99os. See Jacobson, supra note 2 I, at 29 (noting that incumbent reelection rates and margins of victory have declined to forty-year lows). Jacobson also disputes Issacharoff's suggestion regarding the number of uncontested seats. See id. (noting that in 1996 only nineteen seats were uncontested, the lowest number of the entire postwar period). 
TABLE I. RATES OF INCUMBENT REELECTION, U.S. HOUSE AND SENATE, I990-I $998^{51}$

\begin{tabular}{|c|c|c|c|c|c|c|c|}
\hline & 1990 & 1992 & I994 & I996 & I998 & 2000 & $\begin{array}{c}\text { Average } \\
\text { (990- } \\
\text { 2000) }\end{array}$ \\
\hline House & 96.3 & 93.1 & 90.9 & 94.5 & 98.5 & 97.8 & 95.2 \\
\hline Senate & 96.9 & 85.7 & 92.0 & 95.0 & 89.7 & 79.3 & 89.8 \\
\hline
\end{tabular}

Historical evidence also casts doubt on the hypothesis that gerrymandering caused the increase in incumbent safety. In the first round of redistricting following the Court's one-person, one-vote rule, political scientists began noticing an increase in incumbent reelection rates. Many blamed redistricting. ${ }^{52}$ Soon after, however, analysts recognized that those states that redistricted did not have higher rates of incumbent reelection than those that did not undergo redistricting. ${ }^{53}$ And other political scientists noticed that the number of marginal districts had been continually dropping since 1896 or $1932,{ }^{54}$ indicating that the introduction of decennial redistricting could not be to blame. The list of possible causes for the growth of the incumbency advantage is quite long. It includes the rise of candidate-centered politics, the increased use of the perquisites of office (such as porkbarreling, the franking privilege, credit claiming, and casework), and rising campaign costs that inhibit effective challengers. ${ }^{55}$ Gerrymandering, while still a contributing factor, is quite far down on the list.

51 See STANLEY \& Niemi, supra note I8, at 53 tbl.I-I8.

52 See Mayhew, supra note 30, at 306; Tufte, supra note 30, at 548.

53 See Ferejohn, supra note 30 , at 168.

54 James C. Garand \& Donald A. Gross, Changes in the Vote Margins for Congressional Candidates: A Specification of Historical Trends, 78 AM. POL. SCI. REV. I7, 20 (I984) (noting a steady rise in margins of victory between 1896 and 1930 and a similar rise from 1932 to 1980 ); Donald A. Gross \& James C. Garand, The Vanishing Marginals, I824-I980, 46 J. PoL. 224, $227-$ 28 (I984).

55 See Bruce Cain, John ferejohn \& Morris fiorina, The Personal Vote: CONSTITUENCY SERVICE AND ELECTORAL INDEPENDENCE 98-IOO (I987) (emphasizing the candidate-specific, rather than party-specific, factors in incumbent reelection); MORRIS $P$. FIORINA, CONGRESS: KEYSTONE OF THE WASHINGTON ESTABLISHMENT 85-90 (2d ed. I989) (emphasizing the relationship between the growth of congressional staffs and incumbency advantages); Janet M. Box-Steffensmeier, A Dynamic Analysis of the Role of War Chests in Campaign Strategy, 40 AM. J. POL. SCI. 352, 366 (I 996) (finding that incumbents' campaign war chests affect the entry decisions of possible high-quality challeng $\rightarrow$ Gary W. Cox \& Scott Morgenstern, The Increasing Advantage of Incumbency in the U.S. States, I8 LEGIS. STUD. Q. 495, 5 I0 (I993) (arguing that casework and particularistic services are the main causes of the incumbency advantage in state legislatures); Morris P. Fiorina, The Case of the Vanishing Marginals: The Bureaucracy Did It, 7I AM. POL. SCI. REV. I77, I80 (I977) (emphasizing legislative casework as cause for the incumbency advantage in the U.S. House); Mayhew, supra note 30 , at $3 \mathrm{I}_{3}$ (suggesting that the incumbency advantage might flow from lessened reliability of party voting cues). See generally DAVID R. MAYHEW, CONGRESS: THE EleCTORAL CONNECTION (I974). 
It is worth asking whether Issacharoff would have judicial trustbusters target these other, more important, aspects of the incumbency advantage. After all, if the judicial role should morph from rights protector to competition referee, there is no reason to think these other factors that certainly contribute to entrenchment should be immune from judicial scrutiny. If promoting competition becomes the mantra for judicial intrusion into politics, we should expect judges to strike down our campaign finance system and the franking privilege, for starters. Perhaps free air time for challengers would be constitutionally required as well. Moreover, if competitiveness concerns justify a prophylactic rule in the redistricting context, why would the same not be true for all other aspects of the law of politics? If one follows this logic, independent commissions should also be in charge of all ballot access, ballot design, campaign finance, and voter registration laws, to name just a few. In each of these contexts, the two parties can do much more to inhibit effective challenges to their duopoly than they have done through gerrymandering. Issacharoff contends that courts could distinguish between "enabling rules that define the engagement and restraining rules that are designed to frustrate challenge." 56 Yet if the markets paradigm can be used to justify a complete reformulation of redistricting law, despite the highly debatable empirical basis for doing so, there is no reason to think this approach leads to "confined yet effective court oversight to guard against conduct that frustrates democratic accountability." 57

\section{IN DEFENSE OF INSIDER SELF-DEALING IN THE REDISTRICTING PROCESS}

Professor Issacharoff wonders how the case could possibly be made for incumbent control of the redistricting process. As he puts it, "[o]nce we accept that the process of redistricting is subject to manipulation, what possible legitimacy can there be for giving control over the process to those who are most likely to abuse it?"58 One need not merely argue that incumbents are the lesser or equal of all evils, as I do in the discussion of redistricting commissions, ${ }^{59}$ to arrive at a satisfactory answer. Bipartisan and incumbent-protecting gerrymanders have much to commend them.

\footnotetext{
$\rightarrow$ Issacharoff, supra note $\mathrm{I}$, at 627 .

$\rightarrow I d$. at 629 (emphasis added).

$\rightarrow$ Id. at 644-45.

59 See generally infra Section V, pp. 673-79.
} 


\section{A. Representation Versus Competition}

The first advantage is the one that the Gaffney Court found legitimate: bipartisan gerrymanders often produce proportional representation. ${ }^{60}$ When the parties divide a state into politically homogeneous constituencies, the composition of the legislature is more reflective of the underlying partisan composition of the electorate. In contrast, a districting scheme that seeks to maximize district-level partisan competition could lead to a legislature wildly unrepresentative of the partisan preferences of the state's population. ${ }^{61}$

A simple example illustrating the worst-case scenario helps prove this point. In a state with a voting population equally divided in its loyalties, the procompetition redistricter would create as many districts as possible in which Democrats and Republicans each constitute 50\% of the district population. Under such conditions, the slightest shift in voter preferences would lead to a landslide victory for one of the parties. If, for example, a presidential winner has coattails that shift $5 \%$ of the vote to his party, then that party could win almost $100 \%$ of the seats in the legislature, despite the fact that $45 \%$ of the voters voted for the opposition. This, I believe, is what the Gaffney Court meant when it said that a "politically mindless approach" could produce "the most grossly gerrymandered results" ${ }^{62}$ - a statement that Issacharoff finds deeply troubling. ${ }^{63}$

To put the point more plainly, maximizing competition at the district level is not the same as maximizing "consumer welfare" 64 in the economic sphere. Quite the contrary. A system that seeks to maximize district-level competitiveness promises to make the greatest number of voters unhappy with the outcome of the election. To use Issacharoff's analogy, ${ }^{65}$ such a districting scheme would force all the Coke drinkers in a district to swallow Pepsi. In a highly competitive district, nearly half the voters will have voted for the loser.

The state's interest in accurate or proportional representation could also be reformulated as an interest in diversity. Issacharoff worries that bipartisan gerrymanders have "[l]eft behind ... droves of median voters" - that is, the ideologically centrist voters who will cast tie-

60 See Gaffney v. Cummings, 4I2 U.S. 735, 738 (I973).

61 On the inherent tradeoffs in the redistricting process, see CAIN, supra note 28 , at 159-66. Those who defend bipartisan gerrymanders from the standpoint of representation do not mistakenly suppose that they know the true preferences of voters, as Issacharoff hints. $\rightarrow$ Issacharoff, supra note $\mathrm{I}$, at $6 \mathrm{I} 6$. If they are wrong in their assessment, as redistricters often are, then the outcome of the election will differ from their prediction.

62 Gaffney, 4I 2 U.S. at 753.

$63 \rightarrow$ Issacharoff, supra note I, at 6 I 7-18.

$\rightarrow$ Id. at 599 .

$65 \underset{\sim}{\rightarrow}$ id. 
breaking votes between two equally matched candidates in a general election. ${ }^{66}$ As an empirical matter, the data on presidential elections in the I 990 s should allay his fears because most districts cannot be consistently described as politically lopsided. ${ }^{67}$ Moreover, the suggestion that gerrymandering has caused the observed polarization of the parties in the House of Representatives falls victim, once again, to the comparison with the unredistricted U.S. Senate, which has exhibited similar polarization among its members. ${ }^{68}$ Although I might agree that such polarization is a problem, as a theoretical matter politically heterogeneous districts, which give greater voice to the median voter, are not clearly superior to politically homogenous ones. Competing for the median voter naturally draws candidates and parties toward converging ideological positions, blurring their differences in order to capture the voter in the middle. ${ }^{69}$ As a result of such convergence, the parties become more alike and, in the end, voters have less real "choice." Ironically, the single-minded focus on competition has the consequence of undermining what I thought was one of the purposes of the political markets approach to begin with: to promote a vibrant debate among parties of differing views. ${ }^{70}$ A districting strategy that forces parties to compete for centrist, independent voters undermines political diversity at the legislative level, homogenizes the two parties, and misrepresents the underlying population. ${ }^{71}$

$66 \rightarrow i d$. at 628 . To be specific, the median voter in each district will not be the median voter of the state, because each district cannot be a perfect political snapshot of the state. However, a redistricting strategy that seeks to enhance general election competition will homogenize districts such that the median voters in each district will be closer, even if not identical, to the state's median voter.

67 See Figur $\rightarrow$ supra p. 664. Moreover, it should be noted that most states allow nonparty members to vote in party primaries. See Persily, Functional Defense, supra note 7, at 785 n.I 55 . Thus, even if the primary election is the dispositive election, the median voter in the primary electorate is either the same as or similar to the median voter of the general electorate. Therefore, in a state that allows Republicans to vote in the Democratic primary, the Republican minority in a lopsided Democratic district can still play an effective role in picking the Democratic nominee.

68 See norman J. ORnstein, Thomas E. Mann \& Michael J. Malbin, Vital STATISTICS ON CONGRESS 200I-2002, at I8I-82, I92 (2002) (describing the diverging ideological positions of party coalitions in the House and the Senate).

69 See ANTHONy DOWNS, AN ECONOMIC THEORY OF DEMOCRACY 127 (1957).

$70 \rightarrow$ Issacharoff \& Pildes, supra note 6, at 674-8I.

71 One other aspect of campaigns that deserves mention is the increased importance of money to a system of competitive districts. Of course, the observation that democracy is expensive is not alone a convincing reason to favor less competitive districts. It is worth noting, however, that the more competitive the district, the more expensive the campaign. As a result, money would become more important in American elections as competitiveness increased, with more Congressmen "beholden" to those who fund their campaigns. 


\section{B. Popular Incumbents: A Sign of Market Efficiency or Breakdown?}

A related point to the previous one is that bipartisan gerrymanders are desirable precisely because they tend to give the voters what they want: a candidate closer to their ideological preferences. As much as the public may hate Congress as an institution, voters tend to love their individual representatives. That, in the end, is the principal reason incumbents get reelected - because they are popular. As Tables 2 and 3 depict, over the last twenty years $46 \%$ of Americans on average disapproved of Congress, but only 10\% on average disapproved of their own member of Congress.

\section{TABle 2. Percent APPROVAl OF PERFormanCE OF CONGRESS, I980-200072}

\begin{tabular}{|l|c|c|c|c|c|c|c|c|c|c|c|c|}
\hline Year & I980 & I982 & I984 & I986 & I988 & I990 & I992 & I994 & I996 & I998 & 2000 & Avg. \\
\hline Approve & 34 & 34 & 53 & 44 & 52 & 36 & 28 & 32 & 46 & 48 & 52 & 42 \\
\hline Disapprove & 48 & 49 & 35 & 38 & 34 & 55 & 63 & 60 & 47 & 43 & 33 & 46 \\
\hline $\begin{array}{l}\text { Don't } \\
\text { Know }\end{array}$ & I8 & I7 & I 2 & I8 & I4 & 9 & 9 & 8 & 8 & 9 & I5 & I2 \\
\hline
\end{tabular}

TABle 3. PERCENT APPROVAl OF CONGRESSIONAL INCUMBENTS RUNNING FOR REELECTION, I980-200073

\begin{tabular}{|l|c|c|c|c|c|c|c|c|c|c|c|c|}
\hline Year & 1980 & 1982 & 1984 & 1986 & 1988 & 1990 & I992 & I994 & I996 & I998 & 2000 & Avg. \\
\hline Approve & 57 & 52 & 69 & 59 & 66 & 64 & 62 & 59 & 66 & 6 I & 58 & 6 I \\
\hline Disapprove & 8 & 8 & 9 & 8 & 7 & II & I2 & I3 & I4 & I2 & I I & I0 \\
\hline $\begin{array}{l}\text { Don't } \\
\text { Know }\end{array}$ & 34 & 40 & 22 & 33 & 33 & 28 & 26 & 26 & 28 & 20 & 27 & $3 \mathrm{I}$ \\
\hline
\end{tabular}

The drive to increase the number of unsafe seats has the intended consequence of increasing membership turnover (despite the empirically questionable need to do so). Those who draw more competitive districts hope that high-quality challengers will enter the race, put up a fight, and perhaps unseat otherwise entrenched incumbents. Or to

72 National Election Studies, National Election Studies Guide to Public Opinion and Electoral Behavior, at http://www.umich.edu/\% 7 Enes/nesguide/toptable/tab5c_4.htm (last visited Nov. $6,2002)$. The precise survey question was: "Do you approve or disapprove of the way the U.S. Congress has been handling its job?" Id.

73 Id. at http://www.umich.edu/\%7Enes/nesguide/toptable/tab8a_3.htm (last visited Nov. 6, 2002). The precise survey question was: "In general, do you approve or disapprove of the way \{running U.S. House incumbent Representative\} has been handling his/her job?" Id. (alteration in original). 
put it a different way, the competitiveness maximization strategy seeks to limit the opportunity for long-term relationships to form between representatives and the represented. There is something inherently suspicious, under this view, about a cozy and comfortable relationship between an incumbent who easily trounces challengers and a constituency that wants him or her to stay forever.

From the voters' point of view, however, this system is far preferable to one that threatens to change representation every few years. Voters develop relationships with their representatives. Long-term representatives have a chance to learn about and understand the unique problems of their districts and to pursue legislation that remedies those problems. To voters, "entrenched" representatives are the ones who know the most about them and can do the most for them. To put it in the economic terms of the markets paradigm, the "quality" of at least one political product - namely, representation - is not necessarily improved by competition. On the contrary, novice representatives are likely to be systematically inferior to "entrenched" representatives when it comes to the effective representation of their constituents' views.

Moreover, at least where congressional elections are concerned, a state has a truly compelling interest in sending the most senior delegation to Washington that it can. Power in the House of Representatives - committee chairmanships, party and House leadership positions falls largely along lines of seniority. Because senior incumbents are able to serve their state in ways freshmen cannot, a state that threatens its incumbents threatens its own interests. One might respond that seniority is endogenous to the current system and a nationally applied prophylactic rule would merely treat all incumbents the same, such that no state would be hurt by a reduction in seniority across the board. However, the move toward procompetitive nonpartisan districting would have a disparate impact on certain states based on the degree of partisan division in the underlying population. Incumbents in states with electorates highly skewed in favor of one party, such as Massachusetts or Utah, will be safer and likely will have more senior representatives than ones where the creation of competitive districts would come about more "naturally."

\section{Redistricting and Governance}

A myopic focus on competition not only undervalues representation, it also ignores the relationship between districting and governance. The process of choosing representatives is about more than mere translation of preferences or even a battle of ideas; it is about selecting individuals who will administer the government. Although we tend to think of administration as an executive responsibility, administration 
of the legislature is of comparable significance from the standpoint of governance.

Whether the area of concern is the budget or foreign affairs, effective policymaking requires experience. A system of representation intentionally biased against the cultivation of experience undermines the institution of the legislature and weakens it vis-à-vis the other branches of government. The literature on the effect of term limits on state legislatures supports this proposition. ${ }^{74}$ The process of "ritually cleansing" incumbents dumbs down the legislature, and the administration of the legislature as an institution can suffer. Those left with power and expertise are unaccountable, "entrenched" staffers and lobbyists, who are the only ones with significant institutional memory. ${ }^{75}$

The separation of powers is relevant to this inquiry for an additional reason. If the motivation for increasing district competitiveness is a perceived lack of responsiveness to shifting majority preferences, then one might ask whether the basis of representation for the executive and legislature should be the same. On the state level, gubernatorial elections are designed to be directly responsive to shifts in preferences among the state majority. A good argument can be made that the legislature should not be responsive to the identical shifts that would influence a gubernatorial election. The very act of splicing a state into districts assumes that constituency-based representation is different from majoritarian representation. So long as the state's majority has its advocate in the executive, is it necessarily true that the state's majority should control the legislature as well?

This is a more controversial suggestion than the ones that precede it, and I would not push it too far. But it strikes to the core assumption in this debate: that there is something inherently wrong with a legislature that fails consistently to reflect and transmit the changing preferences of a state's majority. ${ }^{76}$ This assumption, which has existed since the original one-person, one-vote cases, considers the legislature

74 See, e.g., John M. Carey, Richard G. Niemi \& Lynda W. Powell, Term Limits in THE STATE LEGISLATURES $65,79,83-85$ (2000) (noting the increased influence of legislative staff, lobbyists, and interest groups); Gary Montcrief, Term Limits from the Lobbyist Point of View, 200I MO. LEGIS. F. 3-5, available at http://www.moforum.org/200I/pdf/moforumoI_ moncrief.pdf (noting the increased influence of the governor, administrative agencies, legislative staff, and lobbyists, along with decreased fundamental knowledge on the issues by the representatives); Daniel M. Weintraub, The Trouble with Term Limits, ST. LEGISLATURES, July/Aug. 2002, at 40,42 (noting a shift in power toward the executive); National Conference of State Legislatures, Survey Results: NCSL's Online Term Limits Poll 5, at http://www.ncsl.org /programs/legman/about/survrslt.htm (last modified Nov. 20, 2000) (suggesting the increased influence of legislative staff and lobbyists in the legislative process in term-limited states).

75 See sources cited supra note 74.

$76: \rightarrow$ Issacharoff, supra note I, at 609 (quoting Michael W. McConnell, The Redistricting Cases: Original Mistakes and Current Consequences, 24 HARV. J.L. \& PUB. POL'y I03, I06 (2000)). 
and its basis of representation in isolation. But when one admits that the chief executive protects the interests of the state's majority, is it really so important for the legislature to be equally responsive to majoritarian pressures? Modern Madisonians might argue that a small dose of legislative entrenchment - especially when turnover still remains at around $15 \%$ per year - is a moderating force on a system that might otherwise be responsive to fleeting majoritarian pressures.

\section{Getting the Politics Out of Politics: Prophylactic RULES AND THE QUIXOTIC QUEST FOR NONPARTISAN REDISTRICTING}

In an attempt to argue against Issacharoff on his own terms, I have resisted until now the temptation to attack what many will consider the most controversial part of his argument: the requirement of a prophylactic rule under which judges would hold "redistricting conducted by incumbent powers [to be] constitutionally intolerable." 77 This intentionally provocative, even if unrealistic and textually unhooked, proposal forces us to consider whether nonpartisan regulation of politics is desirable or even possible. It also challenges us to think of exit strategies from the current incoherent world of redistricting litigation. ${ }^{78}$

\section{A. Porous Prophylactics and the Search for Redistricting in the Public Interest ${ }^{79}$}

No one should fault Issacharoff for his quest to extract the courts from the political thicket of redistricting. As mentioned above, if this strategy would lead to less judicial involvement in redistricting, there would be much to commend it. ${ }^{80}$ As with all rules of decision in this area, however, what appears at first to be an escape hatch is, upon reflection, a trap door. This prophylactic rule, to the extent I understand it, may only add to the number of potential causes for judicial involvement in the redistricting process. Nonpartisan or disinterested

77 Id. at 6oI.

78 See generally Pamela S. Karlan, Exit Strategies in Constitutional Law: Lessons for Getting the Least Dangerous Branch Out of the Political Thicket, 82 B.U. L. REV. 667 (2002) (discussing exit strategies for the Court's Shaw line of cases).

79 See generally Daniel H. Lowenstein \& Jonathan Steinberg, The Quest for Legislative Districting in the Public Interest: Elusive or Illusory?, 33 UCLA L. REV. I (1985) (suggesting that the drawing of districts is inherently political).

80 See supra p. 652. 
redistricting is as loose a standard as "corruption," 81 "race [as] the predominant factor," 82 or even "intent of the voter." 83

It is important to be clear at the outset about what this rule of decision would actually be. Issacharoff does not provide the equivalent of Miranda warnings, and perhaps that would be too much to ask for in this initial presentation of the idea. Given that automated districting, blue-ribbon commissions, and retired judges would pass the test, ${ }^{84}$ we can get a general sense of what might be permitted and prohibited by the prophylactic rule. However, if this rule is to remedy the current constitutional confusion governing redistricting rather than add to the numerous causes of action that losing parties can employ to throw redistricting into the courts, it must be clear as to what qualities in decisionmakers would disqualify them from exercising legitimate redistricting authority.

It would seem that the prophylactic rule would ban redistricting by "incumbent," "partisan," or "self-interested" actors. It would presumably bar a legislature from redrawing a state's congressional districts, even though under such a system neither the relevant incumbents nor self-interested actors draw the lines. The problem with such a system, which after all is the dominant one used for congressional districts, would appear to be the close linkage, based on partisanship, between those in charge of the redistricting process and those whose fates will be determined by it. Thus, it is important to understand that Issacharoff's concern is not limited to self-interested or insider behavior in the limited sense, but applies to officials who will likely act on their preferences as to which party or which candidates should benefit from proposed redistricting.

The first criticism of this proposal is an obvious one: it is almost impossible to design institutions to be authentically nonpartisan and politically disinterested. To return to the examples that began this response, all the high-profile participants in the 2000 election fiasco seemed partisan, and few would suggest that the investigation leading to President Clinton's impeachment was conducted by an independent counsel in the way Issacharoff conceives it. Whoever draws the lines must get authority from somewhere - the person will either be appointed or elected. Elected officials, as former Florida Secretary of State Katherine Harris demonstrated, are almost certainly conflicted. And appointed officials will be beholden to those appointing them or at least selected because their intentions are well-known.

81 See Buckley v. Valeo, 424 U.S. I, 26-29 (1976).

82 Miller v. Johnson, 5 15 U.S. 900, 916 (I995).

$83 \mathrm{See}$ Bush v. Gore, 53I U.S. 98, I05-I I (2000).

$84 \rightarrow$ Issacharoff, supra note I, at 644 . 
Experience with the Federal Election Commission (FEC) and with state redistricting commissions confirms these initial suspicions. The FEC has been described as a commission "designed to fail." 85 It has three Democratic appointees and three Republican appointees, who have historically been vetted and chosen to represent the parties' interests on the Commission. ${ }^{86}$ Indeed, as one recent appointment to the Commission demonstrates, even one who believes the enabling act of the FEC is unconstitutional and is dedicated to the fight against campaign finance reform can get appointed to the Commission. ${ }^{87}$

Most state redistricting commissions follow the FEC model. As set forth in the Appendix, the modal arrangement for such commissions involves appointment by the parties in the legislature or the different branches of government. The prophylactic rule would prohibit almost all of these systems. Even Iowa's "nonpartisan" Legislative Services Bureau, which Issacharoff celebrates, is appointed by and serves at the pleasure of the Legislative Council, which the majority party in the legislature controls. ${ }^{88}$ Moreover, the legislature can veto the plans submitted by the Legislative Services Bureau, as it did to the initial plan proposed this year and did twice in $1980 .{ }^{89}$ The Legislative Services Bureau certainly has a reputation of nonpartisanship quite similar to that of boundary commissions in other countries, and the Iowa legislature has agreed to plans that promote competition. This tradition may have more to do with Iowa's political culture, however, than with features inherent to the institutional form that the state has chosen. One can only wonder if the civil service of more politically confrontational or polarized states would be similarly nonpartisan or receive the mutual assent of all government officials. ${ }^{90}$

85 Benjamin Weiser \& Bill McAllister, The Little Agency That Can't, WASH. PosT, Feb. I2, 1997, at Ar (quoting Frank P. Reiche).

86 See Federal Election Commission, The FEC and the Federal Campaign Finance Law (Aug. I999), http://www.fec.gov/pages/fecfeca.htm.

$87 \mathrm{See}$ Press Release, Brennan Center for Justice, Brennan Center, Common Cause, \& Democracy 2 I Urge President Clinton To Reject Bradley Smith as FEC Nominee (June 3, I999), http://www.brennancenter.org/presscenter/pressrelease_I999_0603.html.

88 Telephone Conversation with Richard Johnson, Deputy Director, Iowa Legislative Services Bureau (July 26, 2002).

89 Id.

90 The Arizona redistricting commission, also praised by Issacharoff, differs from that of Iowa in that Arizona's commission on appellate court appointments selects the initial pool of potential commissioners, from which the leaders of the two parties then select two representatives each. ARIZ. ConST. art. IV, pt. 2, § I(6). Then, the fifth member of the redistricting commission (the chairman) is selected by the other four members, or if they cannot agree, the commission on appellate court appointments selects the chairman while "striving for political balance and fairness." Id. art. IV, pt. $2, \S \mathrm{I}(8)$. The sixteen members of the commission on appellate court appointments include the Chief Justice of the state supreme court, five attorney members nominated by the board of governors of the State Bar of Arizona and appointed by the governor 
Gaffney v. Cummings itself - the Supreme Court opinion that Issacharoff finds particularly objectionable and that provides the springboard for his article - demonstrates the difficulty in constructing nonpartisan institutions to foster political competition. That case involved a bipartisan gerrymander drawn by judges, not by selfinterested or partisan politicians. ${ }^{91}$ Because the Connecticut legislature and a bipartisan commission failed to produce a plan, the task fell to a three-judge board. One judge was appointed by the Democratic Speaker of the House of Representatives, another by the Republican Minority Leader of the House, and those two judges then designated a third, who was a justice of the State Supreme Court. Those judges sought to achieve partisan proportional representation, as Issacharoff rightly points out, and one may have complained that it minimized inter-partisan competition. Ironically, the complaint in the lawsuit that gave rise to the case alleged "the plan amounted to a political gerrymander and contained 'a built in bias in favor of the Republican Party.'" ${ }_{92}$ Whatever else one might learn from the case, Gaffney does not demonstrate the problem of self-interested political manipulation or the need for aggressive judicial relief. If anything, the case serves as a warning to those who would presume that judges are inherently different from politicians in the motivations underlying their redistricting decisions or that "nonpartisan" redistricting necessarily fosters competition.

If nonpartisanship or political disinterestedness is difficult to define or institutionalize, then the prophylactic rule merely becomes one more amorphous cause of action to strike down a districting plan. Whereas litigants have challenged plans on grounds of racial or quantitative vote dilution, excessive use of race, or violations of various state laws, they would now claim in addition (not instead) that the body that drew

\footnotetext{
with the advice and consent of the senate, and ten nonattorney members appointed by the governor with the advice and consent of the senate. Id. art. VI, $\S 36$. In short, the political branches are the initial source for authority over the redistricting process and the two parties can appoint a majority of its members. This involvement of the political branches and party leaders would probably violate the prophylactic rule. However, as Issacharoff rightly points out, the Arizona redistricting commission is prohibited from considering certain political data in the line drawing process. Nevertheless, the commission's plan for the 2000 was not immune from litigation or the charge that it favored Republicans and incumbents. See Editorial, TuCsON Citizen, May 8, 2002, at 6B, LEXIS, News Group File ("Adding to the legal morass, the Minority Coalition for Fair Redistricting, supported by the Democratic Party, also has challenged the maps on the grounds that districts are not politically competitive."); Susan Bitter Smith, Primary Will Decide Most Races, ARIZ. REPUBLIC, Sept. 4, 2002, at 2, LEXIS, News Group File ("Despite the mandate to the Independent Redistricting Commission to create competitive districts, the reality is that a majority of the races in the election cycle will still be determined in the primary election.").

91 See Gaffney v. Cummings, 4I 2 U.S. 735,736 (1973).

92 Id. at 739 .
} 
the lines was insufficiently nonpartisan. ${ }^{93}$ To get out of this bind Issacharoff might redefine the prophylactic rule very specifically, but a hyper-specific rule presents a different set of problems. The procompetition justification for the prophylactic rule is, to put it mildly, far removed from the Republican Form of Government Clause or any other textual command in the Constitution. Were the Court to enact the political equivalent of Miranda warnings not to protect a right, but to promote a vision of democratic government, such a precedent would open up a Pandora's Box not only for the law of politics, but for constitutional law more generally. Prophylactic rules typically act as fences surrounding and protecting a right with some clear textual basis that can shape the contours and content of the prophylactic rule. The enactment of a prophylactic rule grounded on antitrust metaphors and contestable democratic theories would set a dramatic precedent for what amounts to judicial legislation concerning foundational questions of constitutional government.

\section{B. Do We Really Want Alan Greenspan Drawing Districts?}

Even if nonpartisan redistricting were feasible, would it be desirable? The assumption that guides Issacharoff's inquiry is that the redistricting process would be better if politics were taken out of it. As with election regulation more generally, we should ask whether we would really want a world in which unaccountable and disinterested officials make the fundamental decisions concerning representation. In short, if we could find an Alan Greenspan of redistricting, would we be better off?

At the outset, it cannot be overemphasized that the principles used to cabin the discretion of a redistricter and the variables or algorithms thrown into a computer mapping program have predictable political and usually partisan effects. Redistricting cannot be truly randomized or automated. To do so would risk the possibility of creating crazyshaped or noncontiguous districts that stretch from one part of the state to another. At least some principles - such as the traditional districting principles of compactness, contiguity and respect for political subdivisions, as well as the more amorphous category of respecting communities of interest - are necessary to eliminate certain districts all would find objectionable. However, because such "neutral" principles uniformly applied by automated redistricting will have predictable

93 Issacharoff is correct that plans drawn by courts and commissions have fared better at the Supreme Court. : $\rightarrow$ Issacharoff, supra note I, at 647 . I am not sure why this is important as a theoretical matter, and it could change with this redistricting cycle or with the widespread use of such mechanisms if his proposal went into effect. Nevertheless, it is an important piece of evidence suggesting the potential practical benefits that might flow from the prophylactic rule he urges. 
effects in a given demographic context, political officials that choose among those principles can inject their bias at an earlier stage of the redistricting process.

Leaving that objection aside and assuming that we could find a philosopher king whom we could trust both to develop and to apply neutral redistricting principles, we should still hesitate to embrace such a method for determining the building blocks of legislative representation. Although the suggestion evokes a visceral negative reaction, for several reasons politicians should be in charge of politics. Much of this ground was covered in the first sections of this response: concerns about representation and governance are of equal weight to concerns about electoral competition, and there is no philosophically uncontestable reason why judges should force one set of values rather than another down the throat of state governments. More subtly, while the process of redistricting may be considered as determining the rules of politics, it should also be seen as a substantive area of public policy.

On a personal note in support of Issacharoff, I should mention that, like the judges that appointed me, I strove to maintain nonpartisanship in the redistricting processes in which I played a part over the past year. ${ }^{94}$ With nonpartisan expertise, however, often comes detachment from the policy goals of the political branches. For example, it is quite typical for nonpartisan experts to attempt to make district lines as coterminous with political subdivision boundaries as possible. Pursuing such a goal, however, often conflicts with attention to communities of interest that straddle such boundaries and with a state's public policy goal of regionalism in uniting cities and suburbs. Such crossover districts can link the representational fates of richer suburbs with the poorer cities off of whose services suburbanites might be likely to free-ride. Also, the overzealous pursuit of neutral redistricting principles often leads to boundary changes that disrupt ongoing programs, such as environmental or infrastructure projects, instituted by an incumbent for his or her district. ${ }^{95}$

The point of these examples (and there are many others) is not to suggest that incumbent-led redistricting ineluctably leads to furthering legitimate public policy goals or that nonpartisan redistricting prevents their achievement. Although incumbents' knowledge of their districts gives them almost unparalleled expertise as to the effect of a given set

94 I was appointed by courts in New York and Maryland to assist them in drawing congressional and state legislative districting plans.

95 One plan I helped draw moved an uninhabited swamp from one legislator's district to another's. The now-swampless legislator argued that the change would disrupt certain environmental projects that he helped initiate and wanted to see through to completion. The move of this area obviously had no identifiable political or partisan effect. The result, however, could have a tangible public policy effect. 
of lines and insiders are more likely to be sensitive to community concerns, one also cannot ignore the fact that bipartisan or partisan gerrymanders sometimes intentionally disrupt or divide communities and often ignore policy goals en route to creating safe seats. Moreover, hearings before nonpartisan redistricting commissions could help accommodate many of these public policy concerns.

However, these examples illustrate how redistricting can be part of substantive policymaking and administration. Legislative bargains in the redistricting process are not completely detached from others that occur throughout a legislative session. Through redistricting, legislatures not only make the tough value-laden decisions as to how communities should be represented, but they create service relationships between representatives and constituents that fit into larger public policy programs. The removal of politics from redistricting seeks to break these relationships. Indeed, if we take the procompetition argument to its logical conclusion, such relationships are part and parcel of the entrenchment evil that nonpartisan redistricting seeks to remedy.

\section{CONCLUSION: METAPHORICAL MARKETS AND STEALTH RIGHTS CLAIMS}

This response ends where Issacharoff begins: the analogy of redistricting to antitrust law. The Democrats and Republicans are like Coke and Pepsi, he argues, and courts should view their division of the relevant markets with similar suspicion. ${ }^{96}$ This analogy drives the logic of his argument toward the prophylactic rule that would place redistricting as far as possible from self-interested actors.

Whatever its appeal to the field of law and politics more generally, the market analogy to redistricting fits rather poorly. As a threshold matter, it is unclear whether the consumers (in this case, voters) benefit from competition or even desire it. Competition among beverage makers leads to a greater variety of products with lower prices and higher quality than would occur in the absence of competition. Competitive districts, on the other hand, inevitably lead to homogenization of the potential products coming out of the electoral process and leave almost half the political consumers with a bitter taste in their mouths for two or more years. Most voters, I suspect, would prefer to be placed in a district in which most of the people share their political beliefs rather than in a district where half of them do not. Similarly, most voters would prefer to be placed in a district where they vote for the winner rather than the loser.

As Issacharoff notes, there is nothing comparable to product price in the political sphere that might be used to gauge consumer welfare. 
Indeed, the principal reason judges should not create constitutional rules such as the one suggested is that alternative redistricting strategies maximize consumer welfare in different ways. One approach might maximize intradistrict competition, another might try to maximize competition for control of the legislature, another might seek to maximize the number of voters who are happy with their representative, and still others might seek to increase the probability that government will work better. There are tradeoffs for each approach. ${ }^{97}$ Good arguments can defend each approach, but it would be truly remarkable for unelected judges with lifetime appointments to decide that competition is the value that should be placed above all others.

The greatest irony of Issacharoff's approach is that despite its steadfast purpose in moving the law and politics jurisprudence toward background structural questions, in the end it looks quite similar to a rights-based approach after all. ${ }^{98}$ It suffers from the same weakness Issacharoff sees in the Court's current approach: namely, a preoccupation with one democratic value without situating it in the political system as a whole. Perhaps district-level competition is "an independent democratic good"; 99 rules governing redistricting need only be "normatively proper" 100 rather than empirically justifiable; and certain groups, such as moderate voters, should be given greater voice. By breathing those principles into the Constitution and striking down every existing districting system, however, judges would be mandating a particularistic and highly contestable vision of the proper working of American democracy. Those hoping to take the politics out of the redistricting process must be very confident that they have discovered a way to strike the balance between the competing political values central to democratic government. Lacking that confidence, I would leave the ultimate decision to the admittedly self-interested but more account-

97 On the tradeoffs in the redistricting process, see CAIN, supra note 28 , at 52-77; POLITICAL GERRYMANDERING AND THE COURTS (Bernard Grofman ed., I990).

98 One might even say that the approach is itself a rights-based approach, focused on the same right to a meaningful vote that has motivated the Court from Reynolds $v$. Sims, 377 U.S. 533 (I964), to Bush v. Gore, 53 I U.S. 98 (2000). Gerrymandering drains the right to vote of all significance, under this view, because it turns elections into anointings. Although it may seem obvious, why is the right to vote more meaningful in a competitive district than a noncompetitive one? The answer, as I have suggested elsewhere, is somewhat complicated and focuses on the probability that a given voter in the district (all else equal) will cast the tie-breaking vote that will decide the election. As the expected margin of victory grows, as in safe districts, the value of an individual's vote diminishes under this view. Put another way, the safer the district, the less likely that an individual vote will "matter" and the less of a reason for the voter to show up on election day. See Persily, Kousser \& Egan, supra note 27, at I3 I I-I2. Moreover, to the degree that Issacharoff is worried about the effect of bipartisan gerrymanders on the representation of moderate voters, the approach seems like the typical vote dilution argument he decries.

$\rightarrow$ Issacharoff, supra note I, at 622 .

$\rightarrow$ Id. at 626 . 
able political bodies that have found various ways of striking the balance.

\section{APPENDIX}

\section{The COMPOSITION OF STATE REDISTRICTING COMMISSIONS}

\begin{tabular}{|c|c|c|c|c|c|c|c|}
\hline State & $\begin{array}{l}\text { ENABLING } \\
\text { LAW }\end{array}$ & $\begin{array}{l}\text { BODIES } \\
\text { REDIS- } \\
\text { TRICTED }\end{array}$ & SIZE & $\begin{array}{l}\text { TYPE OF } \\
\text { COMMISSION }\end{array}$ & $\begin{array}{l}\text { METHOD OF SELEC- } \\
\text { TION }\end{array}$ & $\begin{array}{l}\text { TIEBREAKING } \\
\text { MEMBER } \\
\text { SELECTION }\end{array}$ & $\begin{array}{l}\text { LEGIS- } \\
\text { LATIVE } \\
\text { VETO? }\end{array}$ \\
\hline ARIZ. & $\begin{array}{l}\text { CoNsT. } \\
\text { art IV }\end{array}$ & $\begin{array}{l}\text { Congres- } \\
\text { sional and } \\
\text { Legisla- } \\
\text { tive }\end{array}$ & 5 & $\begin{array}{l}\text { Bipartisan } \\
\text { (plus tie- } \\
\text { breaker) }\end{array}$ & $\begin{array}{l}\text { State legislative } \\
\text { leaders select two } \\
\text { per party from } \\
\text { pool selected by } \\
\text { commission on } \\
\text { appellate court } \\
\text { appointments }\end{array}$ & $\begin{array}{l}\text { Majority vote } \\
\text { by commis- } \\
\text { sion members } \\
\text { or by com- } \\
\text { mission on } \\
\text { appellate } \\
\text { court ap- } \\
\text { pointment }\end{array}$ & No \\
\hline ARK. & $\begin{array}{l}\text { CONST. } \\
\text { art. VIII, } \\
\$ \S \text { I, 3-4 }\end{array}$ & $\begin{array}{l}\text { Legisla- } \\
\text { tive }\end{array}$ & 3 & $\begin{array}{l}\text { Constitu- } \\
\text { tional } \\
\text { Officers }\end{array}$ & $\begin{array}{l}\text { Governor, } \\
\text { Attorney General, } \\
\text { Secretary of State }\end{array}$ & - & No \\
\hline Colo. & $\begin{array}{l}\text { Const. } \\
\text { art. V, } \\
\S 48\end{array}$ & $\begin{array}{l}\text { Legisla- } \\
\text { tive }\end{array}$ & II & Mixed & $\begin{array}{l}\text { Four members from } \\
\text { the state legislature, } \\
\text { which are the } \\
\text { House Speaker, the } \\
\text { House Minority } \\
\text { Leader, the Senate } \\
\text { Majority Leader } \\
\text { and the Senate } \\
\text { Minority Leader, } \\
\text { unless they select a } \\
\text { replacement; three } \\
\text { members selected } \\
\text { by the Governor; } \\
\text { four members } \\
\text { selected by the } \\
\text { Chief Justice of the } \\
\text { State Supreme } \\
\text { Court. }\end{array}$ & - & No \\
\hline CONN. ${ }^{*}$ & $\begin{array}{l}\text { CONST. } \\
\text { art. III, } \\
\$ 6\end{array}$ & $\begin{array}{l}\text { Legisla- } \\
\text { tive }\end{array}$ & 9 & $\begin{array}{l}\text { Bipartisan } \\
\text { (plus tie- } \\
\text { breaker) }\end{array}$ & $\begin{array}{l}\text { State legislative } \\
\text { party leaders select } \\
\text { four per party }\end{array}$ & $\begin{array}{l}\text { Majority vote } \\
\text { by commis- } \\
\text { sion members }\end{array}$ & No \\
\hline HAW. & $\begin{array}{l}\text { CONST. } \\
\text { art. IV, } \\
\$_{2}\end{array}$ & $\begin{array}{l}\text { Congres- } \\
\text { sional and } \\
\text { Legisla- } \\
\text { tive } \\
\end{array}$ & 9 & $\begin{array}{l}\text { Bipartisan } \\
\text { (plus tie- } \\
\text { breaker) }\end{array}$ & $\begin{array}{l}\text { State legislative } \\
\text { party leaders select } \\
\text { four per party }\end{array}$ & $\begin{array}{l}\text { 3/4 superma- } \\
\text { jority vote by } \\
\text { commission } \\
\text { members }\end{array}$ & No \\
\hline
\end{tabular}

* These states allow for a commission to draw district lines only once the legislature has failed to do so. 


\begin{tabular}{|c|c|c|c|c|c|c|c|}
\hline IDAHO & $\begin{array}{l}\text { Const. } \\
\text { art. III, } \\
\S_{2}\end{array}$ & $\begin{array}{l}\text { Congres- } \\
\text { sional and } \\
\text { Legisla- } \\
\text { tive }\end{array}$ & 6 & Mixed & $\begin{array}{l}\text { State legislative } \\
\text { party leaders select } \\
\text { two per party; state } \\
\text { party leader selects } \\
\text { one per party. }\end{array}$ & - & No \\
\hline ILL.* & $\begin{array}{l}\text { Const. } \\
\text { art. IV, } \\
\S 3\end{array}$ & $\begin{array}{l}\text { Legisla- } \\
\text { tive }\end{array}$ & $\begin{array}{c}8 \\
(+I)\end{array}$ & \begin{tabular}{|l} 
Bipartisan \\
(plus tie- \\
breaker)
\end{tabular} & $\begin{array}{l}\text { State legislative } \\
\text { party leaders select } \\
\text { four per party }\end{array}$ & $\begin{array}{l}\text { State supreme } \\
\text { court nomi- } \\
\text { nates two } \\
\text { candidates; } \\
\text { tiebreaker } \\
\text { selected } \\
\text { randomly. }\end{array}$ & No \\
\hline IowA & \begin{tabular}{|l|} 
Code \\
Ann. 8 \\
42.3
\end{tabular} & $\begin{array}{l}\text { Congres- } \\
\text { sional and } \\
\text { Legisla- } \\
\text { tive }\end{array}$ & - & \begin{tabular}{|l} 
Legislative \\
Services \\
Bureau
\end{tabular} & $\begin{array}{l}\text { The Legislative } \\
\text { Council, controlled } \\
\text { by the majority } \\
\text { party in the legisla- } \\
\text { ture, selects the } \\
\text { director of the } \\
\text { Legislative Services } \\
\text { Bureau } \\
\end{array}$ & - & Yes \\
\hline МICH. & $\begin{array}{l}\text { CoNST. } \\
\text { art. IV, } \\
86 \\
\end{array}$ & $\begin{array}{l}\text { Legisla- } \\
\text { tive }\end{array}$ & 8 & Bipartisan & $\begin{array}{l}\text { State party leaders } \\
\text { select four per } \\
\text { party }\end{array}$ & - & No \\
\hline Miss.* & $\begin{array}{l}\text { CoNST. } \\
\text { art. XIII, } \\
\S 254\end{array}$ & $\begin{array}{l}\text { Legisla- } \\
\text { tive }\end{array}$ & 5 & $\begin{array}{l}\text { Constitu- } \\
\text { tional Offi- } \\
\text { cers }\end{array}$ & $\begin{array}{l}\text { Chief Justice, At- } \\
\text { torney General, } \\
\text { Secretary of State, } \\
\text { House Speaker, } \\
\text { Senate President } \\
\text { Pro Tempore } \\
\end{array}$ & - & No \\
\hline \multirow{2}{*}{ Mo. } & $\begin{array}{l}\text { CONST. } \\
\text { art. III, } \\
\S_{2}\end{array}$ & \begin{tabular}{|l} 
State \\
House
\end{tabular} & $\dagger$ & Bipartisan & $\begin{array}{l}\text { Each party nomi- } \\
\text { nates two members } \\
\text { per congressional } \\
\text { district; Governor } \\
\text { selects one }\end{array}$ & - & No \\
\hline & $\begin{array}{l}\text { Const. } \\
\text { art. III, } \\
\S 7\end{array}$ & \begin{tabular}{|l} 
State \\
Senate
\end{tabular} & I0 & Bipartisan & $\begin{array}{l}\text { Each party nomi- } \\
\text { nates ten persons; } \\
\text { Governor selects } \\
\text { five from each list } \\
\end{array}$ & - & No \\
\hline MONT. & $\begin{array}{l}\text { Const. } \\
\text { art. V, } \\
\S \mathrm{I} 4\end{array}$ & $\begin{array}{l}\text { Congres- } \\
\text { sional and } \\
\text { Legisla- } \\
\text { tive } \\
\end{array}$ & $\begin{array}{c}\text { IO } \\
(+I)\end{array}$ & $\begin{array}{l}\text { Bipartisan } \\
\text { (plus tie- } \\
\text { breaker) }\end{array}$ & $\begin{array}{l}\text { State legislative } \\
\text { party leaders select } \\
\text { two per party }\end{array}$ & $\begin{array}{l}\text { Majority vote } \\
\text { by commis- } \\
\text { sion members }\end{array}$ & $\begin{array}{l}\text { Yes, for } \\
\text { legisla- } \\
\text { tive } \\
\text { districts } \\
\end{array}$ \\
\hline N.J. & $\begin{array}{l}\text { ConsT. } \\
\text { art. IV, } \\
\S 3\end{array}$ & $\begin{array}{l}\text { Legisla- } \\
\text { tive }\end{array}$ & $\begin{array}{c}10 \\
(+I)\end{array}$ & $\begin{array}{l}\text { Bipartisan } \\
\text { (plus tie- } \\
\text { breaker) }\end{array}$ & $\begin{array}{l}\text { Chairpersons of the } \\
\text { state political par- } \\
\text { ties make the } \\
\text { nominations }\end{array}$ & $\begin{array}{l}\text { Chief Justice } \\
\text { of State } \\
\text { supreme } \\
\text { court } \\
\end{array}$ & No \\
\hline
\end{tabular}

$\dagger$ The two parties casting the highest number of votes for governor in the last election have their congressional district committees nominate two members from each congressional district. The governor then selects one nominee from each list. 


\begin{tabular}{|c|c|c|c|c|c|c|c|}
\hline Онго & $\begin{array}{l}\text { CONST. } \\
\text { art. XI, } \\
\S \mathrm{I}\end{array}$ & $\begin{array}{l}\text { Legisla- } \\
\text { tive }\end{array}$ & 5 & Mixed & $\begin{array}{l}\text { Governor, Auditor, } \\
\text { Secretary of State; } \\
\text { legislative leaders } \\
\text { appoint two mem- } \\
\text { bers, one Democrat } \\
\text { and one Republican }\end{array}$ & - & No \\
\hline OKLA. & $\begin{array}{l}\text { CoNST. } \\
\text { art. V, } \\
\S \text { I IA }\end{array}$ & $\begin{array}{l}\text { Legisla- } \\
\text { tive }\end{array}$ & 3 & $\begin{array}{l}\text { Constitu- } \\
\text { tional Offi- } \\
\text { cers }\end{array}$ & $\begin{array}{l}\text { Attorney General, } \\
\text { Treasurer, and } \\
\text { Superintendent of } \\
\text { Public Instruction }\end{array}$ & - & No \\
\hline OR. ${ }^{*}$ & $\begin{array}{l}\text { CoNST. } \\
\text { art. IV, } \\
\$ 6\end{array}$ & $\begin{array}{l}\text { Legisla- } \\
\text { tive }\end{array}$ & I & $\begin{array}{l}\text { Constitu- } \\
\text { tional Officer }\end{array}$ & Secretary of State & - & No \\
\hline PA. & $\begin{array}{l}\text { CoNST. } \\
\text { art. II, } \\
\S \mathrm{I} 7\end{array}$ & $\begin{array}{l}\text { Legisla- } \\
\text { tive }\end{array}$ & 5 & $\begin{array}{l}\text { Bipartisan } \\
\text { (plus tie- } \\
\text { breaker) } \\
\end{array}$ & $\begin{array}{l}\text { State legislative } \\
\text { party leaders select } \\
\text { two per party }\end{array}$ & $\begin{array}{l}\text { Majority vote } \\
\text { by commis- } \\
\text { sion members }\end{array}$ & No \\
\hline TEX. ${ }^{*}$ & $\begin{array}{l}\text { CONST. } \\
\text { art. III, } \\
\S 28\end{array}$ & $\begin{array}{l}\text { Legisla- } \\
\text { tive }\end{array}$ & 5 & $\begin{array}{l}\text { Constitu- } \\
\text { tional Offi- } \\
\text { cers }\end{array}$ & $\begin{array}{l}\text { Lieutenant Gover- } \\
\text { nor, Attorney Gen- } \\
\text { eral, House } \\
\text { Speaker, Comptrol- } \\
\text { ler, Land Office } \\
\text { Commissioner }\end{array}$ & - & No \\
\hline WASH. & $\begin{array}{l}\text { CONST. } \\
\text { art. II, } 43\end{array}$ & $\begin{array}{l}\text { Congres- } \\
\text { sional and } \\
\text { Legisla- } \\
\text { tive }\end{array}$ & 5 & $\begin{array}{l}\text { Bipartisan } \\
\text { (with non- } \\
\text { voting chair- } \\
\text { man) }\end{array}$ & $\begin{array}{l}\text { State legislative } \\
\text { party leaders select } \\
\text { two per party }\end{array}$ & $\begin{array}{l}\text { Majority vote } \\
\text { by commis- } \\
\text { sioners select } \\
\text { a nonvoting } \\
\text { chairman }\end{array}$ & $\begin{array}{l}\text { Yes, } \\
2 / 3 \\
\text { majority }\end{array}$ \\
\hline
\end{tabular}

Explanation of categories:

Enabling Law: Constitutional or statutory provision that provides for the creation of a districting commission.

Bodies Redistricted: Whether the redistricting commission has the authority to redistrict state legislative districts, congressional districts, or both.

Size: Number of members on the commission.

Type of Commission: General description of the redistricting commission's membership. "Bipartisan" means that the commission is composed of persons appointed by both major parties in the state legislature. "Constitutional Officer" means that the commission is composed of executivebranch officials as established by the state's constitution. "Mixed" means the commission contains both "bipartisan" members (appointed by the legislature) and "constitutional officers" (executivebranch officials). "Legislative Services Bureau" is unique to Iowa and is described in the text.

Method of Selection: Method for selecting the members of the commission.

Tiebreaking Member Selection: Method for selecting the so-called "tiebreaker" member of a redistricting commission, who is usually selected in a manner different than the rest of the members of the commission.

Legislative Veto?: Does the legislature retain the authority to amend or reject the redistricting commission's plan? 